\title{
Relative sea-level change and postglacial isostatic adjustment along the coast of south Devon, United Kingdom
}

\author{
ANTHONY C. MASSEY, ${ }^{1}$ W. ROLAND GEHRELS, ${ }^{1 *}$ DAN J. CHARMAN, ${ }^{1}$ GLENN A. MILNE, ${ }^{2}$ W. RICHARD PELTIER, ${ }^{3}$ \\ KURT LAMBECK ${ }^{4}$ and KATHERINE A. SELBY ${ }^{5}$ \\ ${ }^{1}$ School of Geography, University of Plymouth, Plymouth, UK \\ ${ }^{2}$ Department of Earth Sciences, University of Durham, Durham, UK \\ ${ }^{3}$ Department of Physics, University of Toronto, Toronto, Ontario, Canada \\ ${ }^{4}$ Research School of Earth Sciences, Australian National University, Canberra, ACT, Australia \\ ${ }^{5}$ School of Geography, University of Southampton, Southampton, UK
}

\begin{abstract}
Previous sea-level studies suggest that southwest Britain has the fastest subsiding coastline in the United Kingdom, but tide-gauge data, GPS and gravity measurements and geophysical models show little evidence of anomalous subsidence in this region. In this paper we present 15 new sea-level index points from four coastal barrier systems in south Devon. Eight are from compaction-free basal sediments and others were corrected for autocompaction. Our data suggest that relative sea level along the south Devon coastline has risen by $21 \pm 4$ m during the past 9000 years. Sea-level rise slowed during the middle and late Holocene and a rise of $8 \pm 1 \mathrm{~m}$ has occurred since ca. $7000 \mathrm{cal}$. yr BP. Anomalous ages for many rejected points are attributed to sediment reworking during barrier transgression. The relative sea-level history during the early and middle Holocene shows a good fit with geophysical model predictions, but the geological and modelled data diverge in the later Holocene. Unlike the geophysical models, sea-level index points cannot differentiate between late Holocene relative sea-level histories of south Devon and southwest Cornwall. It is suggested that this discrepancy can be resolved by obtaining additional high-quality sea-level index points covering the past 4000 years. Copyright (C) 2008 John Wiley \& Sons, Ltd.
\end{abstract}

KEYWORDS: isostasy; sea-level change; Holocene; foraminifera; England.

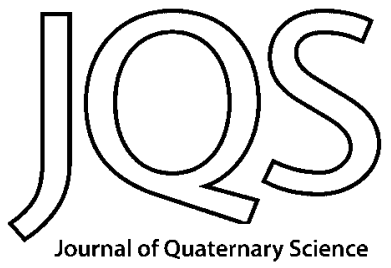

\section{Introduction}

The British Isles are of interest to the study of postglacial isostatic adjustment and relative sea-level (RSL) change, given their position marginal to the Scandinavian and British Isles ice sheets at the Last Glacial Maximum (LGM). The southwest of England was ice-free during the LGM; its postglacial relative sea-level history has implications for understanding of proglacial forebulge dynamics, a flexing of the lithosphere near the ice margin that migrates and eventually collapses as the land-based ice retreats (e.g., Walcott, 1970; Peltier, 1974). The British Isles have been a traditional testing ground for geophysical modellers (e.g., Lambeck, 1993a,b, 1995; Peltier, 1998; Peltier et al., 2002; Milne et al., 2006; Shennan et al., 2006) and new relative sea-level data are useful to develop and test models of ice retreat and Earth rheology.

*Correspondence to: W. R. Gehrels, School of Geography, University of Plymouth, Plymouth, Devon, PL4 8AA, UK.

E-mail: wrgehrels@plymouth.ac.uk
Postglacial sea-level studies around the British Isles were summarised by Shennan (1989). In an update of this work, Shennan and Horton (2002) determined that the coastline of southwest England is currently undergoing relative subsidence at a faster rate than other coasts in Britain $\left(\sim 0.9-1.4 \mathrm{~mm} \mathrm{yr}^{-1}\right)$. Recent GPS measurements indicate absolute subsidence rates of $0.0 \pm 0.5 \mathrm{~mm} \mathrm{yr}^{-1}$, while subsidence determined by gravity measurements is $0.9 \pm 0.9 \mathrm{~mm} \mathrm{yr}^{-1}$ (Teferle et al., 2006). The sea-level rise measured by the tide gauge at Newlyn, Cornwall, since 1916 is not indicative of anomalous subsidence in southwest England, as the rate of rise $\left(\sim 1.6 \mathrm{~mm} \mathrm{yr}^{-1}\right)$ does not differ significantly from the global average (Woodworth et al., 1999).

The Channel coasts of Devon and Cornwall have produced only 18 scattered sea-level index points (SLIPs) (Shennan and Horton, 2002; Waller and Long, 2003; Massey, 2004). Information on the indicative meaning of these points is often lacking in detail and many data points cannot be precisely related to a former tide level (Haslett et al., 1997; Massey et al., 2006a). Only four of the available sea-level index points were used by Shennan and Horton (2002) in their analysis of regional 
subsidence: two for Cornwall and two for Devon. Their findings are in disagreement with those of Waller and Long (2003), who concluded, based on an analysis of almost the same dataset, that southeast England may have subsided relative to southwest England. The discrepancy between these two, seemingly opposite, conclusions can be explained by sediment consolidation (or 'autocompaction', i.e. the compression of a sediment sequence by the weight of the overlying sediments). This process may have affected as many as 14 sea-level index points from Devon and Cornwall and most index points in southern England and Wales (Waller and Long, 2003; Edwards, 2006). The most reliable sea-level index points are obtained from the base of Holocene sediments where they overlie a hard substrate. Only four basal index points have been obtained from southwest Cornwall (Healy, 1995) and none from south Devon.

There is no commonly accepted methodology that is used to correct sea-level index points for autocompaction (e.g., Pizzuto and Schwendt, 1997; Paul and Barras, 1998; Rybczyk et al., 1998; Tovey and Paul, 2002; Williams, 2003; Bird et al., 2004; Massey et al., 2006b; Edwards, 2006). This is in part due to the lack of geotechnical models capable of dealing with the complex stratigraphies found in coastal sediments (Allen, 1999; Massey et al., 2006b; Shennan et al., 2006). However, samples from thick unconsolidated Holocene sediments are likely to have experienced significant post-depositional lowering (Allen, 1995, 2000; Shennan and Horton, 2002) and more so those from organic-rich sediments, thereby affecting rates of relative sea-level change calculated from sea-level index points (Massey et al., 2006b). Sea-level histories corrected for autocompaction are likely to change estimates of late Holocene relative land movement (Shennan and Horton, 2002).

The quantification of vertical errors attached to sea-level index points is fundamental to the precise determination and comparison of sea-level histories. To date no quantitative studies have been produced in southwest England to assess indicative meaning (the height at which a sea-level indicator was deposited relative to a reference tide level; Shennan, 1983). In this study this is achieved using an intertidal foraminifera-based transfer function (Massey et al., 2006a).

\section{Study sites}

Four coastal back-barrier systems were selected during a pilot study in 1997 based on the presence of basal organic units (Fig. 1). The barrier at Bantham Sands $\left(50^{\circ} 16.60^{\prime} \mathrm{N} ; 03^{\circ} 52.51^{\prime}\right.$ W) (Fig. 1(A)) is part of a dune system reaching $+15 \mathrm{~m}$ OD that separates a back-barrier freshwater marsh from the sea. The back-barrier marsh at North Sands $\left(50^{\circ} 13.77^{\prime} \mathrm{N} ; 03^{\circ} 46.93^{\prime} \mathrm{W}\right)$ (Fig. 1(B)) is located at the mouth of the Salcombe-Kingsbridge Estuary, a submerged valley that was fronted by a barrier ('The Bar') (Fig. 1(E)) when sea level was lower in the early Holocene. Slapton Sands $\left(50^{\circ} 16.96^{\prime} \mathrm{N} ; 03^{\circ} 38.80^{\prime} \mathrm{W}\right)$ (Fig. 1(C)) is a shingle barrier that separates a reed swamp and shallow freshwater lake from Start Bay. Blackpool Sands $\left(50^{\circ} 19.17^{\prime} \mathrm{N}\right.$; $03^{\circ} 36.78^{\prime} \mathrm{W}$ ) (Fig. 1(D)) is an extension of Slapton Sands to the north (Hails, 1975a, 1975b), and protects a reclaimed backbarrier marsh from Start Bay. The regional underlying solid geology is primarily Lower Devonian slate and shale (Ussher, 1904). The tidal range in our study area varies from $4.6 \mathrm{~m}$ in southwest Devon to $4.3 \mathrm{~m}$ in the southeast (Hydrographic Office, 2002) (Table 1).

\section{Methods}

\section{Coring and surveying}

Coring was carried out in 1997 and 1999 using a percussion drilling rig to extract $1 \mathrm{~m}$ sections in hard plastic tubes. Partial recovery in some tubes was attributed to the settling of fine waterlogged sand following removal above the water table (Rees, 1999). Core loss was recorded at the base of these sections. Core compaction was measured in the field. A sediment catcher was attached to the base of each tube to prevent sediment loss upon extraction and 'captured' sediment was retained in a bag. Twelve boreholes were surveyed to UK Ordnance Datum (Newlyn) using an electronic distance measurer (EDM) and local Ordnance Survey (OS) benchmarks. Borehole positions were determined with a hand-held global positioning system (GPS) (Fig. 1). Core sections were stored at $+4^{\circ} \mathrm{C}$. All cores were logged in detail using the Troels-Smith (1955) classification scheme, but stratigraphy is generalised in this paper for clarity of presentation. Additional information on subsurface stratigraphy is provided in Massey et al. (2006c).

\section{Geotechnical correction}

Autocompaction was calculated in two cores from North Sands and two cores from Blackpool Sands using the Paul and Barras (1998) model. Methods and classifications are based on standard techniques (e.g. Terzaghi, 1925; Terzaghi et al., 1996). Plastic and liquid limits (Atterberg, 1911) were calculated at $1 \mathrm{~m}$ intervals to determine sediment compressibility (British Standard 4691, 1974; British Standard 1377, 1975). Particle size analysis (PSA) of the $<2 \mathrm{~mm}$ fraction was carried out using a Laser Mastersizer autosampling system and the $>2 \mathrm{~mm}$ fraction using a Camsizer (particle size and shape analyser). PSA served as a check for the Atterberg (1911) limits and did not form part of the model input. Sections were sampled every $20 \mathrm{~cm}$ for water content and bulk sediment density, the methods conforming generally to British Standard 1377 (1975) using a sediment moisture sampler. Further details are reported in a separate paper (Massey et al., 2006b).

\section{Foraminiferal analysis}

Standard techniques were used to sample and analyse foraminifera (Scott and Medioli, 1980a,b; Gehrels, 2002). Foraminifera were identified in $5 \mathrm{~mL}$ sediment samples at $2-5 \mathrm{~cm}$ intervals in the cores. A minimum of 300 foraminifera per sample were counted where possible. The sampling resolution was increased to 1 or $2 \mathrm{~cm}$ intervals when whole samples contained $<50$ foraminifera at crucial levels (e.g. sample horizons selected for dating and reconstructing palaeoenvironments).

Foraminiferal taxonomy is based on Murray (1979), Scott and Medioli (1980b), Loeblich and Tappan (1987) and de Rijk (1995). Some species were classified to a single generic level for ease of description, e.g. Elphidium spp. include E. earlandi, $E$. gerthi and E. incertum, and Quinqueloculina spp. include $Q$. dimidiata, Q. cliarensis, Q. oblonga and Q. seminulum. Generic names are in accordance with Loeblich and Tappan (1987). Agglutinated juveniles deemed unclassifiable due to 

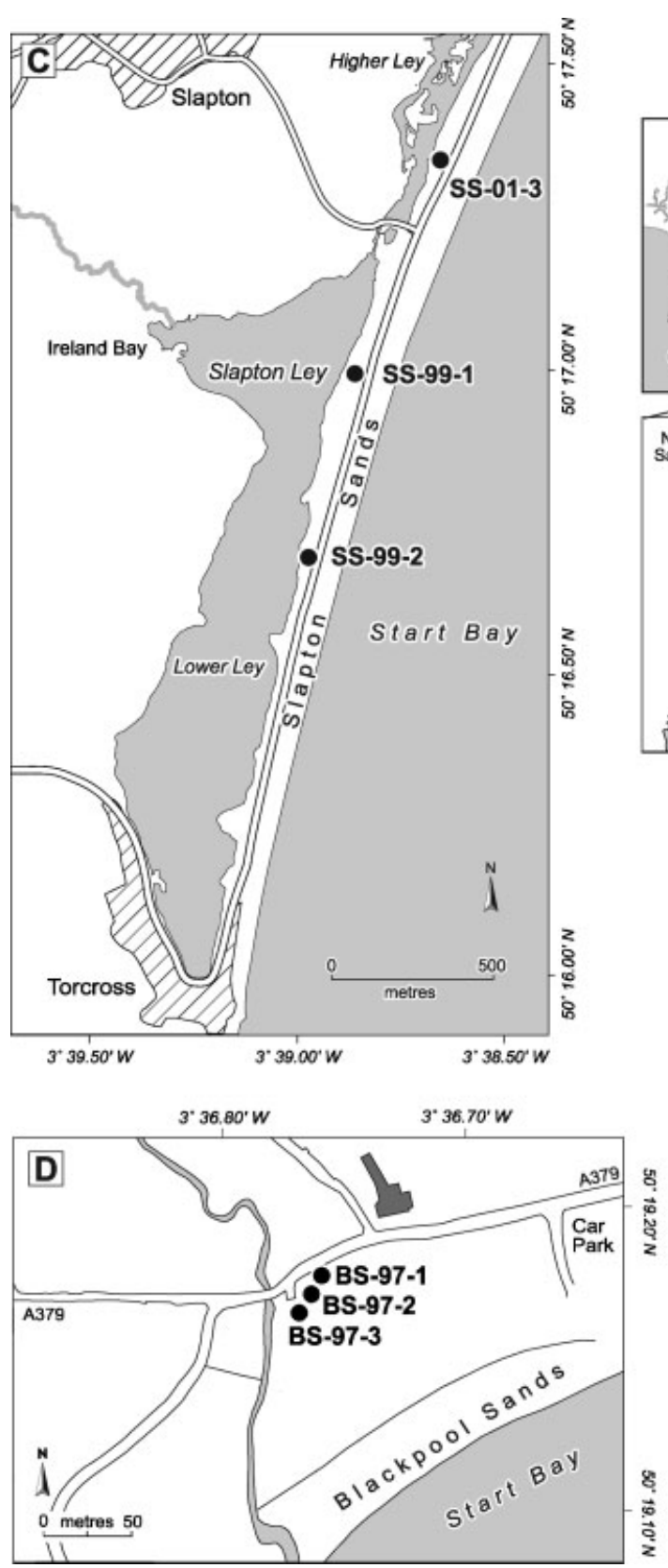
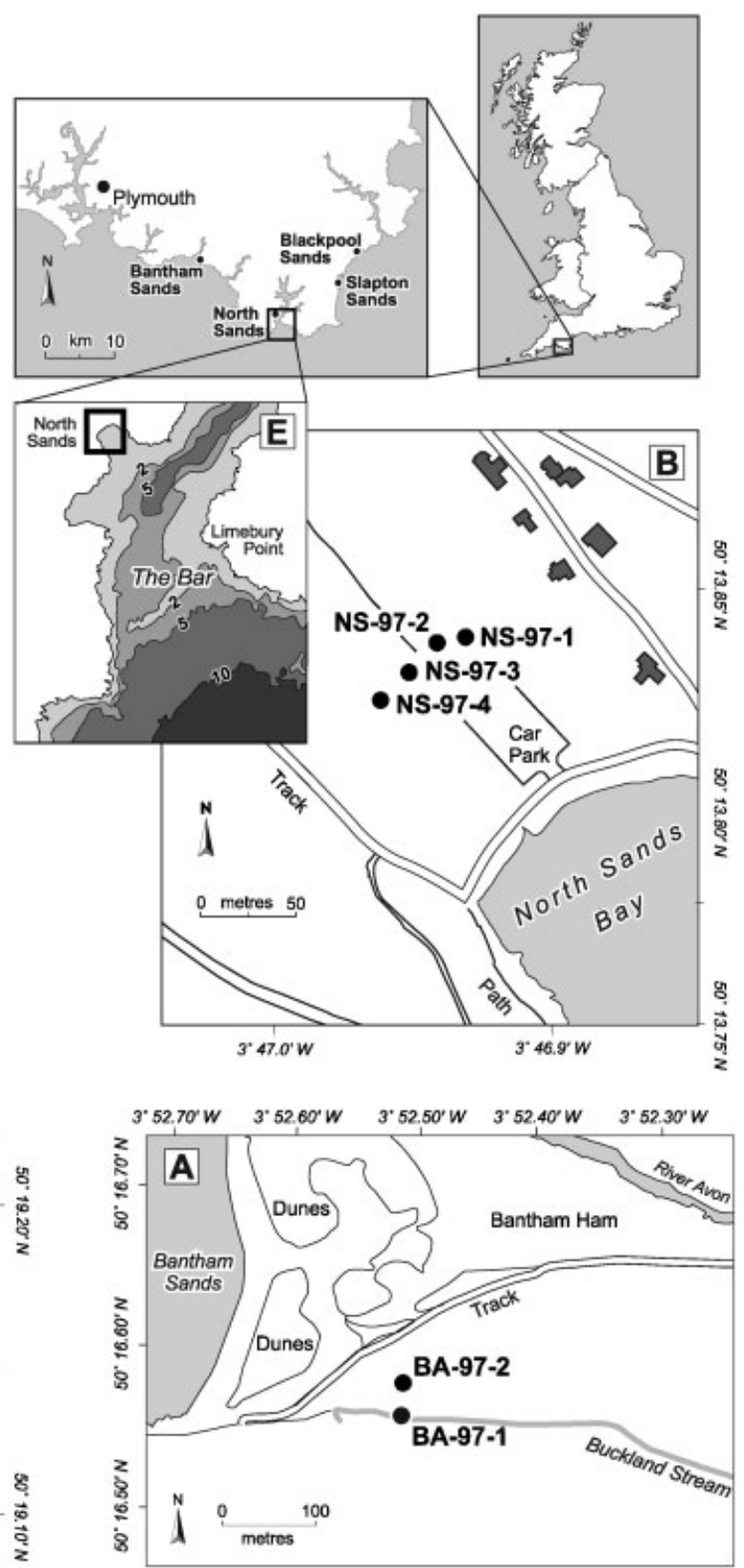

Figure 1 Location of boreholes at Bantham Sands (A), North Sands (B), Slapton Sands (C) and Blackpool Sands (D), south Devon. Also shown is 'The $\mathrm{Bar}^{\prime}(\mathrm{E})$, a subtidal feature which probably represents a former barrier fronting the palaeovalley of the Salcombe-Kingsbridge Estuary. (C) Crown Copyright/Database right 2006. An Ordnance Survey/EDINA supplied service. Reproduced with the permission of Ordnance Survey/EDINA supplied service

their simple test form were recorded as 'unidentified'. A few partially dissolved calcareous specimens were easily identified by their test lining (Edwards and Horton, 2000).

The indicative meaning for each sample was calculated using a regional transfer function to reconstruct palaeowater levels from fossil core records based on 113 modern intertidal samples (Massey et al., 2006a). The $C^{2}$ programme (Juggins, 2003) was used to estimate palaeoelevation from a weighted averaging-partial least squares model and the root mean squared error of prediction ( $\pm 0.29 \mathrm{~m}$ ) (Massey et al., 2006a).

Table 1 Tidal heights interpolated from nearest tidal stations

Tidal station/site

Bantham Sands (River Avon entrance)

North Sands (Salcombe Harbour entrance)

Slapton Sands (Start Bay)

Blackpool Sands (Start Bay)

Latitude $\mathrm{N}$ Longitude W MHWST $(\mathrm{m}) \quad \mathrm{MLWST}(\mathrm{m}) \quad$ Tidal range $(\mathrm{m}) \quad$ Chart datum $(\mathrm{m}) \quad$ MTL $(\mathrm{m})$

$\begin{array}{lllllll}50^{\circ} 17^{\prime} & 3^{\circ} 53^{\prime} & 2.29 & -2.35 & 4.64 & -3.05 & 0.11 \\ 50^{\circ} 13^{\prime} & 3^{\circ} 47^{\prime} & 2.25 & -2.35 & 4.60 & -3.05 & 0.09 \\ 50^{\circ} 17^{\prime} & 3^{\circ} 38^{\prime} & 2.28 & -2.06 & 4.34 & -2.98 & 0.12 \\ 50^{\circ} 19^{\prime} & 3^{\circ} 36^{\prime} & 2.25 & -2.07 & 4.32 & -2.95 & 0.11\end{array}$

Heights are relative to the UK Ordnance Datum.

MHWST, mean high water of spring tides; MLWST, mean low water of spring tides; MTL, mean tide level.

Source: Hydrographic Office (2002). 


\section{Radiocarbon dating}

Basal units in cores were dated to provide compaction-free sea-level index points. Other levels of the core, in sections containing salt-marsh foraminifera, were also dated to provide additional index points. In most cores detrital plant macrofossils, the preferred material for dating, were not well preserved in sediments and bulk sediment samples or small wood fragments were used instead. Samples were prepared to graphite at the Natural Environment Research Council (NERC) Radiocarbon Laboratory in East Kilbride, Scotland. Accelerator mass spectrometry (AMS) ${ }^{14} \mathrm{C}$ analyses were carried out at the National Science Foundation-AMS Facility, University of Arizona (North Sands), and the Center for Accelerator Mass Spectrometry, Lawrence Livermore National Laboratory at the University of California (Bantham, Slapton and Blackpool Sands). Calibrations follow Stuiver et al. (1998) using the Calib 4.2 program (cf. Stuiver and Reimer, 1993) (Table 2).

\section{Pollen analysis}

Following radiocarbon dating, pollen analysis was used as a further age check on ${ }^{14} \mathrm{C}$ age determinations, to evaluate continuity of the sediments and a possible hiatus in one core from North Sands. Pollen was sampled, prepared and analysed according to Moore et al. (1991). Sediment samples of $2 \mathrm{~mL}$ were initially selected adjacent to ${ }^{14} \mathrm{C}$ horizons then increased to $\sim 5 \mathrm{~cm}$ intervals throughout for a detailed reconstruction of pollen zones. A target of 300 total land pollen grains per sample was set but this was difficult to achieve for some basal samples (counts $<80$ ) and the majority of slides analysed from other sections (counts 100-200). These samples also contained a significant number of damaged grains. Identification followed Andrews (1984) and Moore et al. (1991) and nomenclature follows Stace (1991) and Bennett et al. (1994).

\section{Sea-level index points}

The altitude of sea-level index points (SLIPs) is calculated according to Gehrels (1999):

$$
\operatorname{SLIP}(\mathrm{m} \mathrm{MTL})=H-D-I+A+C
$$

where $H=$ height of the ground surface in metres above or below MTL; $D=$ sample depth below ground level in metres; $I=$ indicative meaning of the sample in metres above or below MTL as calculated from counts of fossil foraminifera by a transfer function (Massey et al., 2006a); $A=$ autocompaction of the sediment as determined by geotechnical correction; and $C=$ core compaction resulting from drilling as determined by measuring the length of retrieved sediment in each $1 \mathrm{~m}$ core tube. The vertical precision of our sea-level estimate is $\pm 0.35 \mathrm{~m}$, a value based on our transfer function analyses (Massey et al., 2006a) and levelling errors (Gehrels et al., 1996; Shennan and Horton, 2002). Full details of sea-level index points are reported in Table 2 and foraminiferal counts associated with the points are shown in Table 3. The stratigraphic context and chronology are described below, followed by an evaluation of the validity of some data points.

\section{Results}

\section{Bantham Sands}

Basal sediments at Bantham Sands comprise fractured slates below $-12.50 \mathrm{~m}$ OD (Fig. 2(A)). The overlying sequence, to about $-7.0 \mathrm{~m}$ OD, consists predominantly of clay and silt. A fine silty-sand sequence was found from about -7.0 to $-2.0 \mathrm{~m}$ OD. Wood and peat dominate the uppermost sediments, but in core BA-97-2 fine sand, blown in from the adjacent dune field, caps the sequence.

The basal sediments in core BA-97-1 contain no or very few foraminifera (Fig. 3(A)). The core section between 16.0 and $15.7 \mathrm{~m}$ is dominated by agglutinated foraminifera, in particular the salt-marsh species Jadammina macrescens and Trochammina inflata. Above this, species indicative of low salt-marsh and tidal mudflat, e.g. Haynesina germanica and Ammonia beccarii, increase to $60-80 \%$. The first occurrence of high numbers of agglutinated foraminifera at $15.91 \mathrm{~m}$ provides SLIP 1 on bulk sediment, with a median age of ca. 8390 cal. yr BP and an indicative meaning of ca. $+2.5 \mathrm{~m} \mathrm{MTL}$ (Tables 2 and 3).

The foraminiferal assemblages are similar throughout the base of core BA-97-2 (Fig. 3(B)). High numbers of mixed agglutinated and calcareous species occur within $5 \mathrm{~cm}$ of the base and provide an indicative meaning of $+0.4 \mathrm{~m} \mathrm{MTL}$. A date on a wood fragment at $17.12 \mathrm{~m}$ (ca. $7885 \mathrm{cal}$. yr BP) provides SLIP 2 (Table 2).

\section{North Sands}

Fractured slates, sand and gravel are found below the unconsolidated basal sediments at North Sands (Fig. 2(B)). Basal organic units are identified in all four cores. Silty-clay sediments occur up to $\sim-7 \mathrm{~m}$ OD in the longer cores NS-97-1 and NS-97-2. Wood peat caps the sequence at North Sands above $\sim-7 \mathrm{~m}$ OD.

The basal $30 \mathrm{~cm}$ of sediments in core NS-97-1 contains no foraminifera but there are significant numbers (up to 800 tests per $5 \mathrm{~mL}$ ) of calcareous foraminifera (mostly $\mathrm{H}$. germanica) in the sediments above this (Fig. 4(A)). Bulk sediment at $16.54 \mathrm{~m}$ has an indicative meaning of ca. $-0.9 \mathrm{~m} \mathrm{MTL}$ (Table 3 ) and provides SLIP 3, dated to ca. 7900 cal. yr BP (Table 2).

There are low but countable numbers of foraminifera in the base of core NS-97-2 (Fig. 4(B)). The basal portion of the core is dominated by J. macrescens, providing SLIP 4 at $15.85 \mathrm{~m}$ with an indicative meaning of ca. $+2.2 \mathrm{~m} \mathrm{MTL}$ and dated to ca. 8180 cal. yr BP. At $15.42 \mathrm{~m}$, agglutinated species dominate the total assemblage and provide SLIP 5 (ca. 8200 cal. yr BP, indicative meaning ca. $+1.8 \mathrm{~m} \mathrm{MTL}$ ) (Tables 2 and 3). Both dated samples are bulk sediment.

Core NS-97-3 contains a sequence of alternating foraminiferal assemblages dominated by either agglutinated or calcareous species. Large variations in abundance occur between 11.15 and $9.39 \mathrm{~m}$ depth. We have divided the foraminiferal stratigraphy into assemblage zones based on cluster analysis (Grimm, 1987) (Fig. 4(C)). Eleven AMS ${ }^{14} \mathrm{C}$ ages on bulk sediment provide the chronology for core NS-97-3 (index points 6-16) (Table 2) but significant age reversals occur in the two lowermost core sections (Fig. 2(B) and Table 2). These are assessed in the Discussion.

Foraminifera are present in some of the basal samples in core NS-97-4 (Fig. 4(D)), with significant numbers of calcareous species between 6.97 and $6.95 \mathrm{~m}$. A date on a minerogenic 


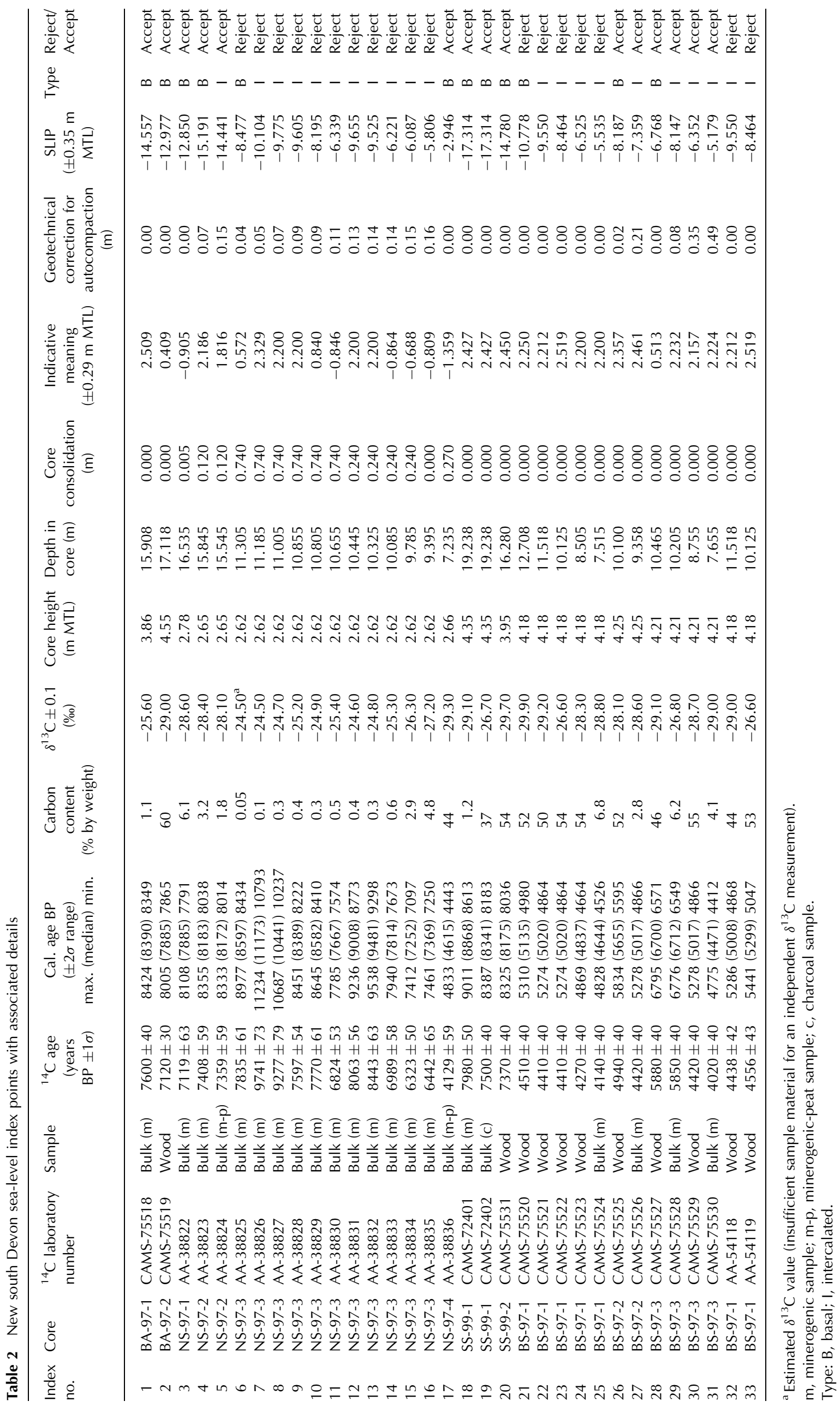




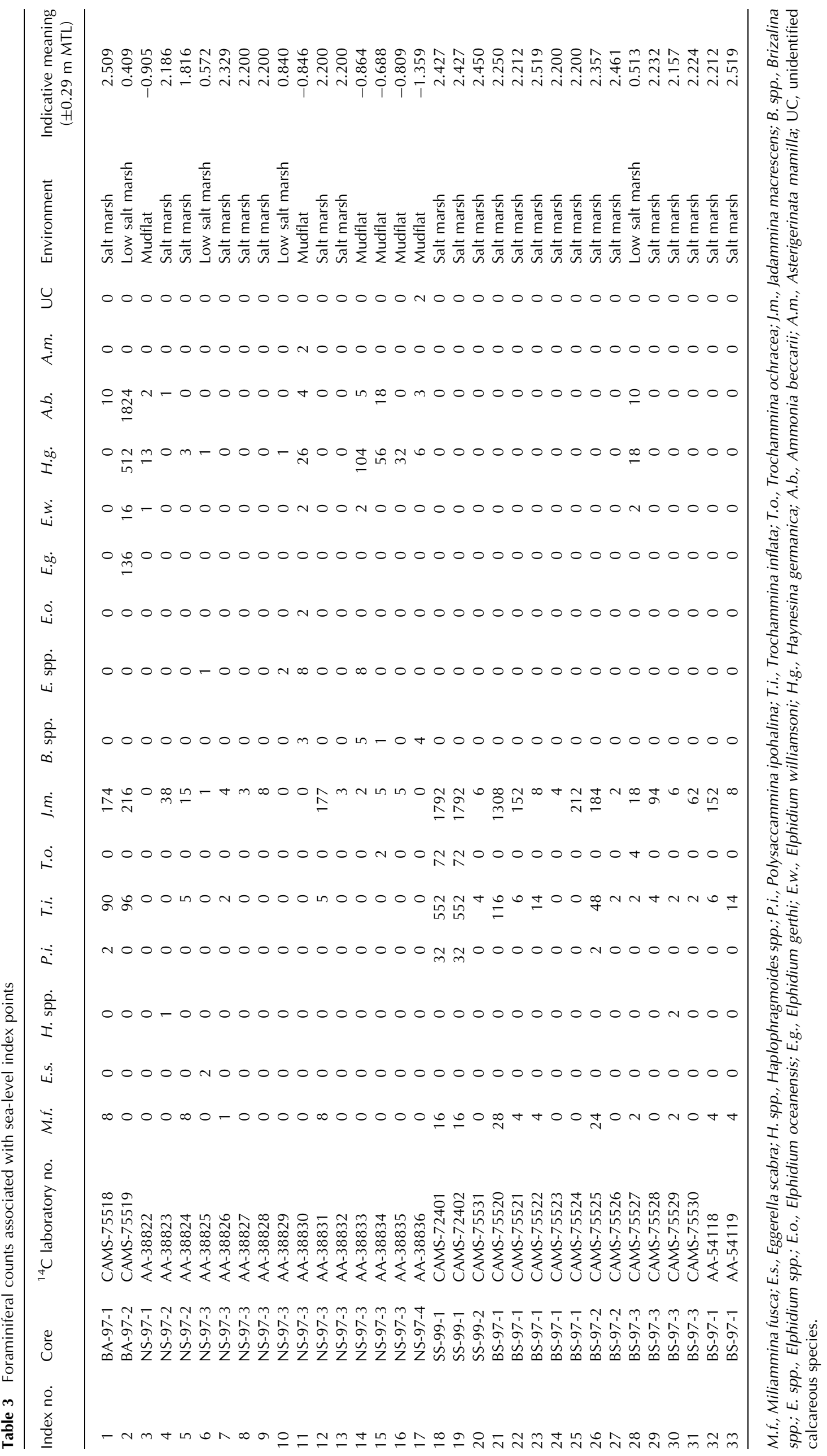


A. Bantham Sands

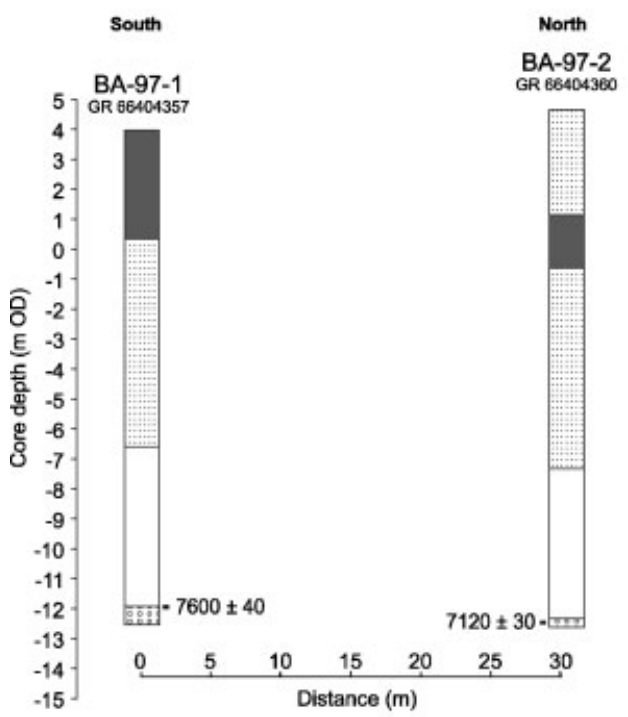

B. North Sands

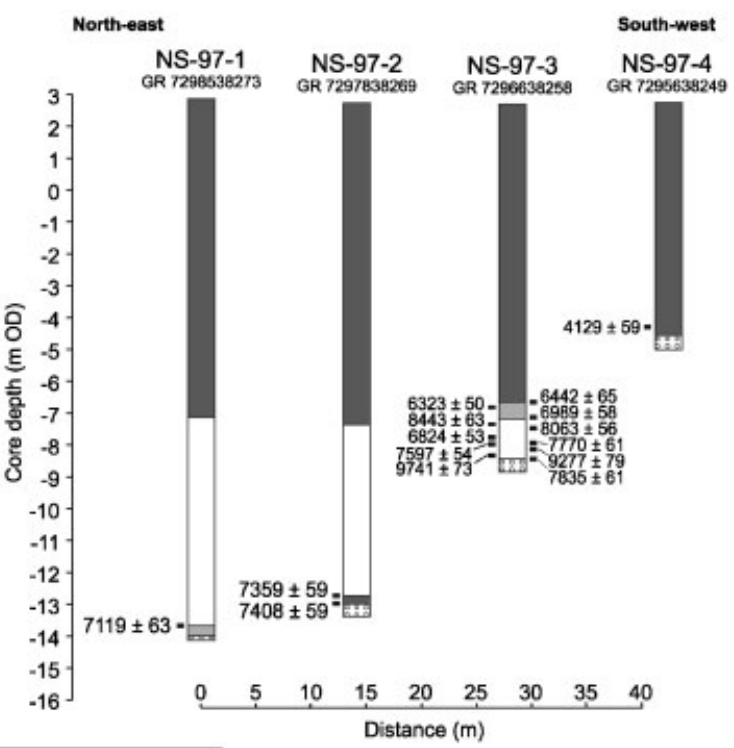

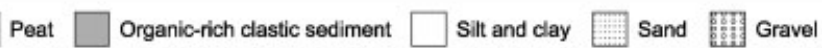

\section{Slapton Sands}

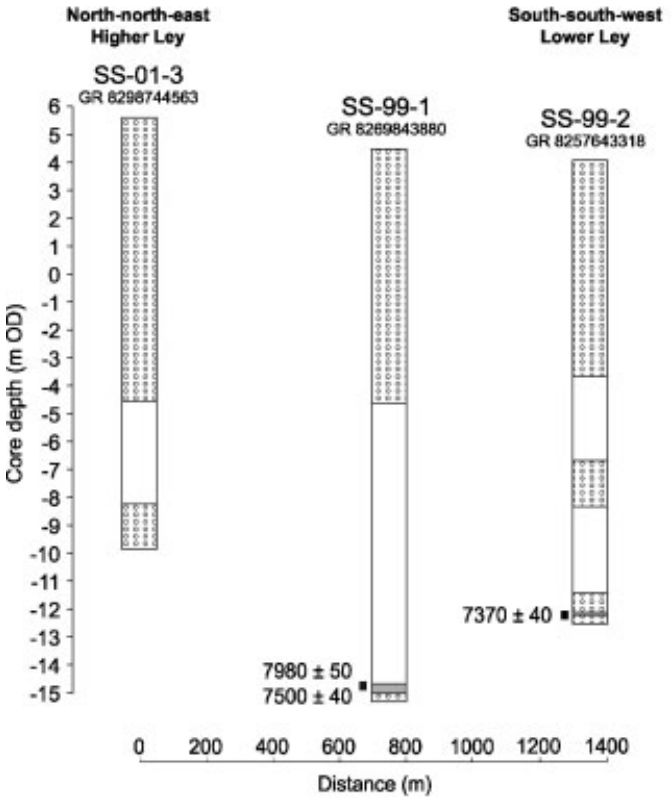

D. Blackpool Sands

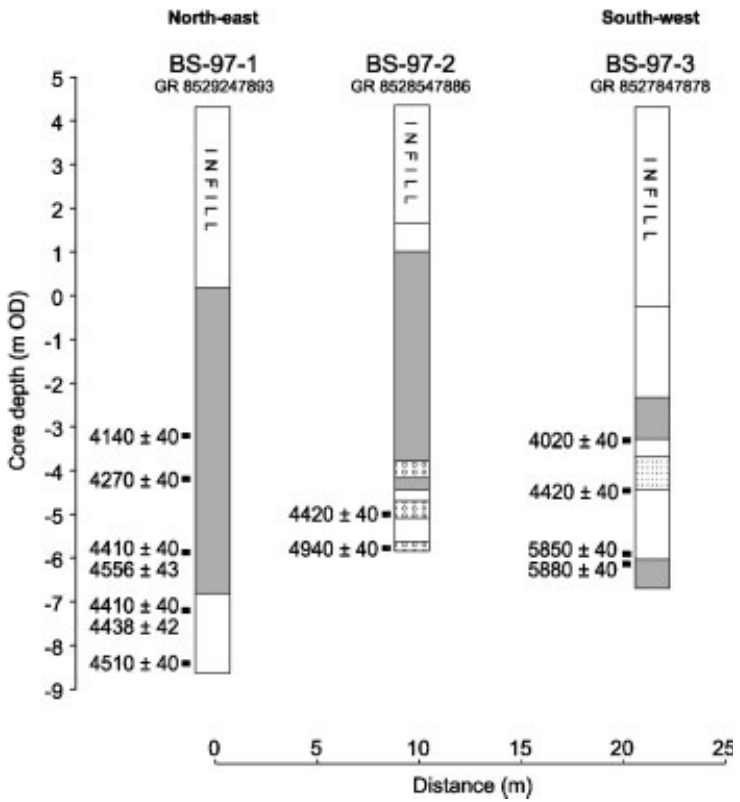

Figure 2 Coastal sediment stratigraphy at Bantham Sands (A), North Sands (B), Slapton Sands (C) and Blackpool Sands (D), south Devon. Core heights are relative to UK Ordnance Datum (Newlyn, Cornwall). Index numbers listed alongside cores correspond to sea-level index points in Table 2. Lithology follows key in Fig. 2

peat sample provides index point 17 at $7.24 \mathrm{~m}$, dated to ca. $4800-4400$ cal. yr BP with an indicative meaning of ca. $-1.4 \mathrm{~m}$ (Table 3).

\section{Slapton Sands}

At Slapton Sands, a broken and weathered slate substrate is found around $-15 \mathrm{~m}$ to $-8 \mathrm{~m}$ OD (Fig. 2(C)). Organic remains are preserved at the base of the two deepest cores (Fig. 5). A thick sequence of silts and clays is found between -14 and $-3 \mathrm{~m}$ OD. This is broken by units of coarse gravel in core SS-99-2 between -8.5 and $-4.5 \mathrm{~m}$ OD. Alternating beds of gravel and silts/clays occur from around -3.8 to $-3.2 \mathrm{~m}$ OD and the sequence is capped by barrier gravels up to $10 \mathrm{~m}$ in thickness.

Biostratigraphical analyses were carried out on cores SS-99-1 and SS-99-2. The base of core SS-99-1 contains the agglutinated salt-marsh foraminifera J. macrescens, $T$. inflata and $M$. fusca (Fig. 5(A)), providing SLIPs 18 and 19, with an indicative meaning of ca. $+2.4 \mathrm{~m} \mathrm{MTL}$ (Tables 2 and 3). Bulk sediments (SLIP 18; ca. 8870 cal. yr BP) and charcoal from the same sample were dated separately (SLIP 19; ca. 8340 cal. yr BP). Above this, there is a gradual decline in agglutinated species and an increase in $A$. beccarii and $H$. germanica, indicating a gradual drowning of a salt-marsh environment and a transition to tidal mudflat conditions.

At the base of core SS-99-2, Phragmites and large alder fragments $(\sim 16.30 \mathrm{~m})$ are present in peat $(16.33-16.26 \mathrm{~m})$ but there are no foraminifera (Fig. 5(B)). Above this level, the 

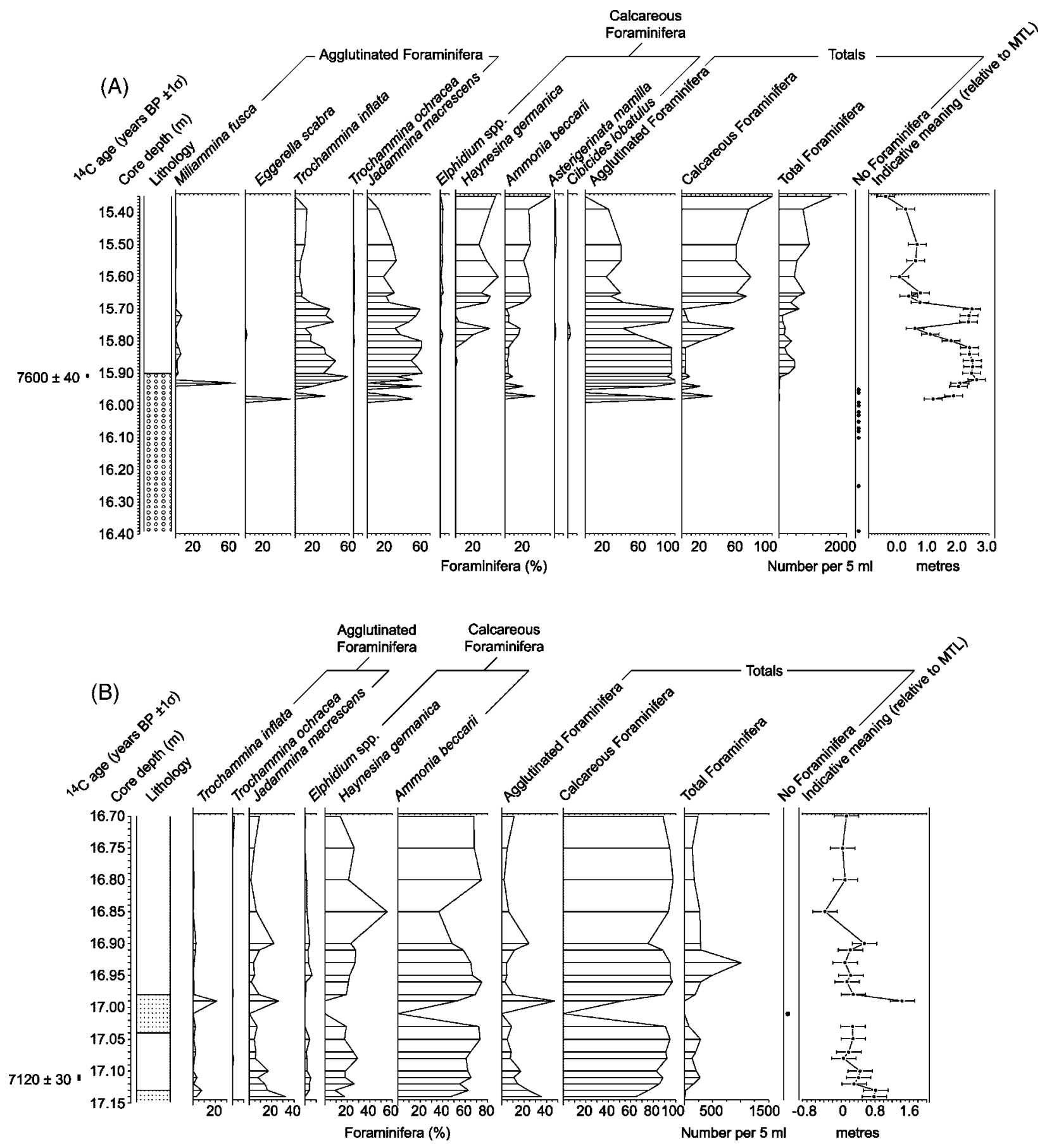

Figure 3 Foraminiferal stratigraphy of Bantham Sands cores BA-97-1 (A) and BA-97-2 (B)

foraminiferal assemblage initially consists of $100 \%$ salt-marsh foraminifera (J. macrescens and T. inflata), falling to $35 \%$ within $2 \mathrm{~cm}$. A $2 \mathrm{~cm}$ long chunk of alder, found at $16.28 \mathrm{~m}$, provided a date of ca. 8175 cal. yr BP (SLIP 20; indicative meaning ca. $+2.5 \mathrm{~m} \mathrm{MTL}$ ) (Tables 2 and 3). Above this, calcareous species dominate most of the core and the total numbers increase. The most dominant species are $A$. beccarii and, in the upper part of the section, Elphidium margaritaceum. The latter is a nearshore (deeper water) species and signifies a change to subtidal conditions (Murray, 1979).

\section{Blackpool Sands}

Basal sediments at Blackpool Sands below $-6 \mathrm{~m}$ OD are fractured slates, sandy and clayey silts and gravel (Fig. 2(D)). A thick sequence of alternating clastic and organic-rich sediments occurs throughout most of the cores. Above ca. $0 \mathrm{~m}$ OD sediments are artificial infill.

The foraminiferal stratigraphy at Blackpool Sands consists mostly of salt-marsh species, but abrupt changes to calcareous assemblages are present. The base of core BS-97-1 from 12.90 to $7.50 \mathrm{~m}$ (Fig. 6(A)) is dominated by $H$. germanica and A. beccarii, abruptly succeeded by J. macrescens above $12.74 \mathrm{~m}$. Above a section where core loss occurred, the assemblage consists of $90-100 \%$ calcareous foraminifera. Another abrupt change, to low counts of agglutinated salt-marsh species, mostly J. macrescens, $T$. inflata and $M$. fusca, occurs at $11.63 \mathrm{~m}$. This assemblage is found up to $7.50 \mathrm{~m}$. Higher in the core section foraminifera are absent. The chronology of core BS-97-1 spans ca. 5300-4525 cal. yr BP (SLIPs 21-25, 32 and 33) (Table 2) but the close spread of 
ages suggests possible sediment reworking. This issue is assessed in the next section.

Agglutinated foraminifera dominate the base of core BS-97-2 between 10.17 and $9.35 \mathrm{~m}$, mostly J. macrescens, T. inflata and M. fusca (Fig. 6(B)). No foraminifera were found above this level. The top and bottom of this section provide SLIPs 26 and 27 suggesting salt-marsh conditions ca. 5835-4865 cal. yr BP (indicative meaning ca. $+2.4 \mathrm{~m} \mathrm{MTL}$ ) (Tables 2 and 3).

Foraminifera are present in core BS-97-3 from between 10.48 and $7.62 \mathrm{~m}$ (Fig. $6(\mathrm{C})$ ). At the base there is a transition from calcareous to agglutinated assemblages and the latter persist throughout the examined sections. No foraminifera were found above $7.60 \mathrm{~m}$. SLIP $28(10.47 \mathrm{~m})$ was collected from tidal mudflat sediments dated at ca. 6700 cal. yr BP (indicative meaning ca. $+0.5 \mathrm{~m} \mathrm{MTL}$ ), while SLIPs 29-31 contained salt-marsh foraminifera (indicative meaning ca. $+2.2 \mathrm{~m} \mathrm{MTL}$ ) (Tables 2 and 3).

\section{Discussion}

\section{Evaluation of anomalous data}

Thirty-three possible sea-level index points were obtained from coastal back-barrier sites in south Devon (Table 2, Fig. 8). Results show that index points from cores NS-97-3 and BS-97-1 are potentially subject to irreconcilable age or height errors.

In core NS-97-3 reversals occur in the chronology (Table 2). Index points 7 and 8 are ca. $2000 \mathrm{yr}$ older than index point 6 , and index points 12 and 13 are ca. $1000 \mathrm{yr}$ older than index points 9, 10 and 11. All dates are on bulk sediment. We evaluate these age reversals using pollen stratigraphy (Fig. 7).

Pollen analyses show that the sediments in core NS-97-3 contain a fairly mixed assemblage of predominantly Quercus, Corylus and Alnus pollen. Lower sediments have a greater proportion of Quercus pollen and less Ulmus (Fig. 7). The presence of Alnus suggests that the sediments must post-date ca. 8000-7500 cal. yr BP (Birks, 1989) and upper sediments with Ulmus must pre-date the elm decline at ca. $5300{ }^{14} \mathrm{C}$ yr BP (Parker et al., 2002). Four index points $(7,8,12$ and 13) are in direct conflict with the pollen stratigraphy, as the sediment contains alder pollen and their ages are 11200-8700 cal. yr BP (Fig. 7).

We interpret core NS-97-3 to have sampled a section of reworked sediments containing old carbon. On the basis of pollen stratigraphy alone it is not possible to determine whether the ages of some of the younger index points are accurate, but we consider it likely that the entire section has been affected by reworking to some degree. We therefore choose to err on the side of caution and reject all dates from this core as SLIPs.

In core BS-97-1 all dates from a $5 \mathrm{~m}$ section of core are within a 500-year range. Four of these are obtained from wood fragments and one date is on bulk sediment. The foraminifera are mostly indicative of a salt-marsh environment and high sedimentation rates (on the order of a metre per century) can therefore be ruled out. The core also contains abrupt changes between agglutinated and calcareous assemblages, which points to discontinuous sedimentation. We conclude that this entire section is also reworked and possibly represents the infilling of a creek by eroded salt-marsh deposits. This mechanism is not implausible given the setting of the site in a narrow and steep palaeovalley. We reject all dates from core BS-97-1 for our sea-level reconstructions.

The basal index point 17 from core NS-97-4 is a critical constraint on RSL change between 7000 and 4000 cal. yr BP. It plots higher than four new index points of similar age $(26,27$, 30, 31) (Fig. 8(A)), which have been corrected for vertical displacement by compaction. It is possible that the indicative meaning of index point 17 ( $-1.4 \mathrm{~m} \mathrm{MTL})$, which is based on low counts of calcareous foraminifera, is too deep. At the base of core NS-97-4, the lithostratigraphy (minerogenic peat) and biostratigraphy (calcareous foraminifera) are in disagreement and if the date is assigned a salt-marsh indicative meaning, for example, the point would place ca. $3 \mathrm{~m}$ lower in the sea-level plot. Alternatively, it is possible that the geotechnical correction for the four index points $(26,27,30,31)$ has underestimated their true vertical displacement (Massey et al., 2006b). Published data points 34 and 35, which seem to agree with points $26,27,30$ and 31 , are intercalated points and may also have been affected by compaction. When we consider all available data we are unable to resolve this issue and uncertainty of the sea-level changes between 7000 and 4000 cal. yr BP therefore remains relatively large (Fig. 8).

Due to a chronic lack of available plant macrofossils in the sediments we dated many small wood fragments. Wood fragments are not ideal dating material as they are prone to post-depositional transport. Perhaps fortuitously, a closer inspection of the accepted wood dates (index points 2, 20, $26,28,30)$ does not reveal any anomalous ages.

In the discussion below we elaborate further on possible mechanisms for the reworking of sediments. It will also be shown that the samples from cores NS-97-3 and BS-97-1 are anomalous, in terms of height and age, in comparison with sea-level index points from other cores. The rejection of index points from the two cores leaves us with 15 validated new SLIPs for south Devon.

\section{Holocene relative sea-level history of south Devon}

Of 15 new sea-level index points that can be used to reconstruct the Holocene relative sea-level history of south Devon, eight are basal SLIPs between ca. 9000 and 6000 cal. yr BP. The other seven (intercalated) points have been corrected for autocompaction (Table 2). In Fig. 8(A) we have drawn an envelope based on the validated sea-level index points for south Devon. The data reveal an overall rise in RSL of $21 \pm 4 \mathrm{~m}$ since ca. $9000 \mathrm{cal}$. yr BP. Since ca. $7000 \mathrm{cal}$. yr BP, sea level has risen by $8 \pm 1 \mathrm{~m}$ (Fig. 8 ).

The slowdown of relative sea-level rise to $\sim 1 \mathrm{~m} \mathrm{ka}^{-1}$ at ca. 7000 cal. yr BP is in agreement with estimates from other regions in southern England and Wales (Heyworth and Kidson, 1982; Healy, 1995; Shennan and Horton, 2002; Waller and Long, 2003; Edwards, 2006). Two index points older than $7000 \mathrm{cal}$. yr BP have previously been published for south Devon and Cornwall $(39,40)$. These are limiting dates obtained from freshwater sediments (Clarke, 1970; Hails, 1975b) (Table 4). These index points and two $(34,35)$ from Hails (1975a) are in line with our new data (Fig. 8(A)).

Our study does not contribute any new sea-level index points younger than 4000 years. Three previously published data points exist (Hails, 1975a, 1975b; Morey, 1976) (Table 4). However, one of these index points is from a tree stump (36), while the others are from intercalated freshwater coastal fen peat $(37,38)$. They are limiting dates (i.e. sea level must be below the points), so that they appear to have been vertically displaced by compaction. Their indicative meaning is only constrained by pollen and should not be considered as valid sea-level index points (as discussed in detail by Gehrels, 2006). The average rate of relative sea-level rise in the late Holocene 


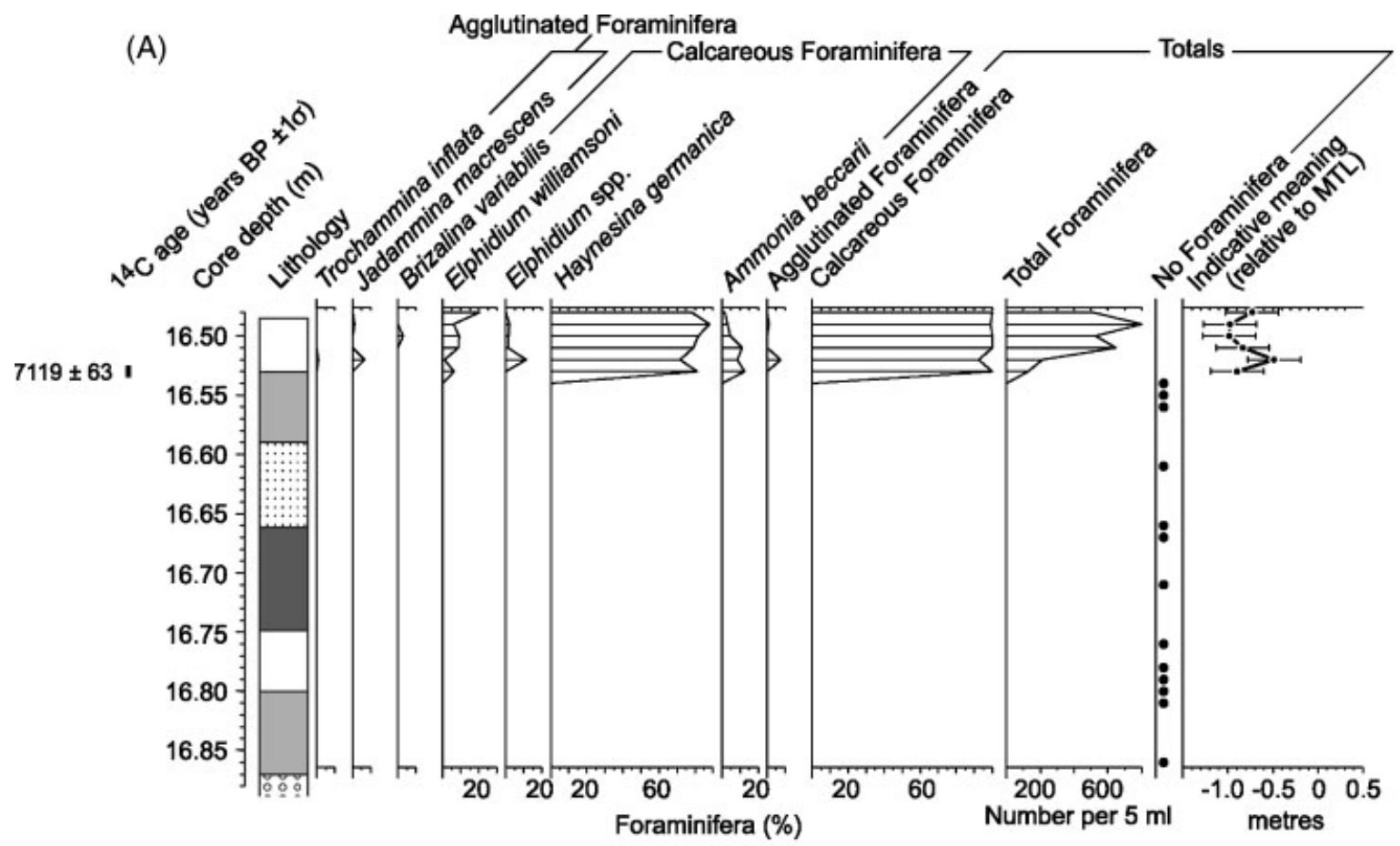

(B)

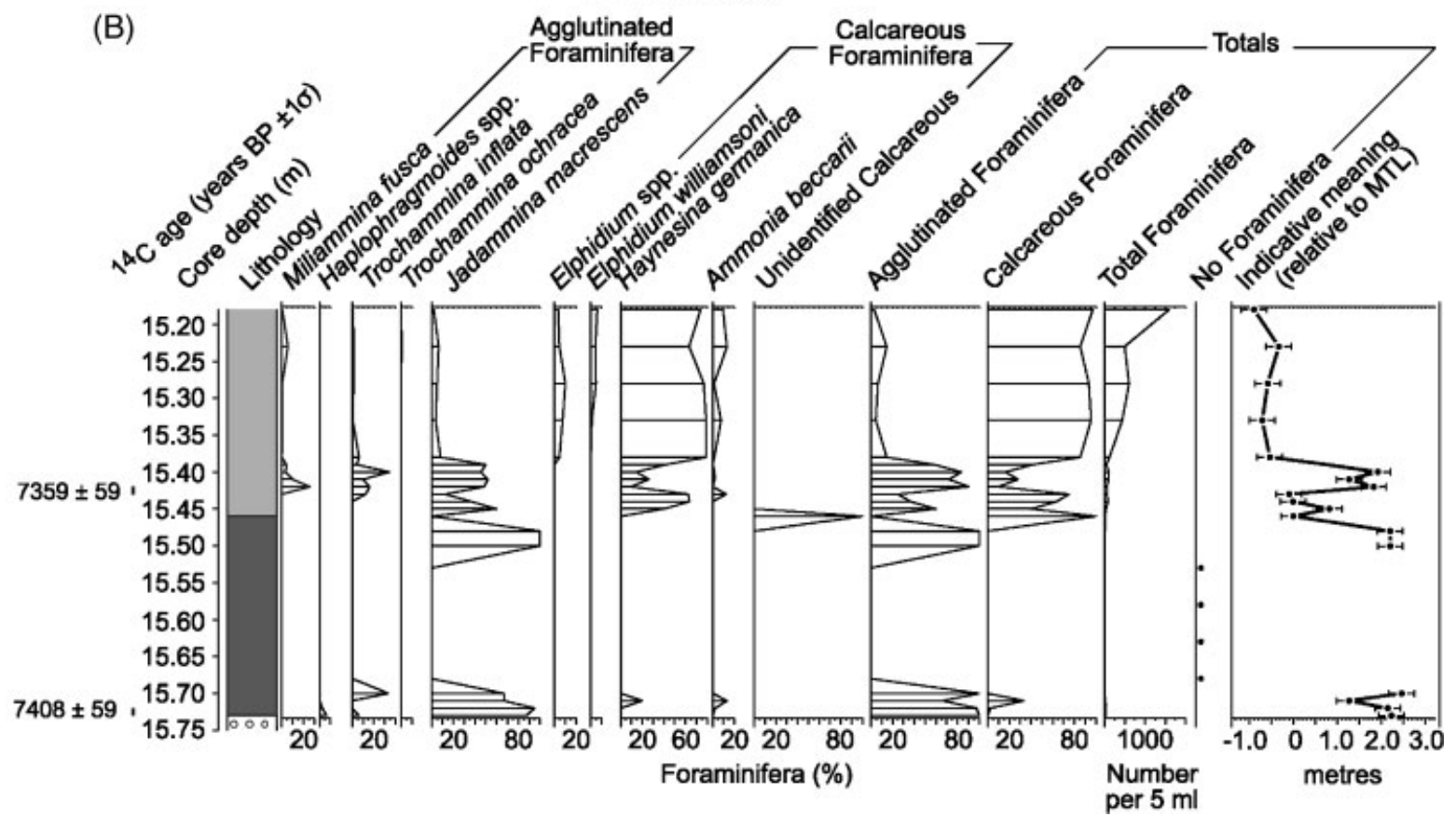

Figure 4 Foraminiferal stratigraphy of North Sands cores NS-97-1 (A), NS-97-2 (B), NS-97-3 (C), and NS-97-4 (D). Zonation in (C) is based on CONISS (Grimm, 1987)

calculated by Shennan and Horton (2002) was based on the two youngest of these dates $(36,37)$.

Postglacial isostatic adjustment along the coast of south Devon

In an initial assessment, Shennan (1989) calculated rates of $0.1-1.4 \mathrm{~m} \mathrm{ka}^{-1}$ relative subsidence in southwest England using Mörner's (1984) sea-level curve for the Kattegat area in Sweden as a 'eustatic' regional baseline curve from which regional curves around the British Isles were subtracted. As the concept of 'regional eustasy' is not widely accepted (e.g. Gehrels et al., 2006), Shennan and Horton (2002) undertook a reanalysis, adding many sea-level index points to the UK dataset and making corrections for tidal range along the UK east coast. They also evaluated problems of autocompaction and in their sea-level age-altitude graphs selected the points towards the higher end of the error envelopes for their analysis. This resulted in a reduced rate of relative subsidence for southeastern England compared to the previous estimates of Shennan (1989). For Devon, Shennan and Horton (2002) used index points 36 and 37 to calculate $1.23 \pm 0.18 \mathrm{~m} \mathrm{ka}^{-1}$ of relative land subsidence. They used index points 42 and 45 to determine $1.12 \pm 0.21 \mathrm{~m} \mathrm{ka}^{-1}$ of relative subsidence for Cornwall. Unlike Waller and Long (2003), they did not consider the data from the Isles of Scilly (Ratcliffe and Straker, 1996). Shennan and Horton's (2002) method of calculating relative land movements also differed from Shennan (1989), by assuming that since ca. 5000-4000 cal. yr BP the long-term eustatic contribution of ice sheets has been zero and that any relative sea-level signal since that time is primarily a function of isostatic crustal movement. It should be noted, therefore, that 

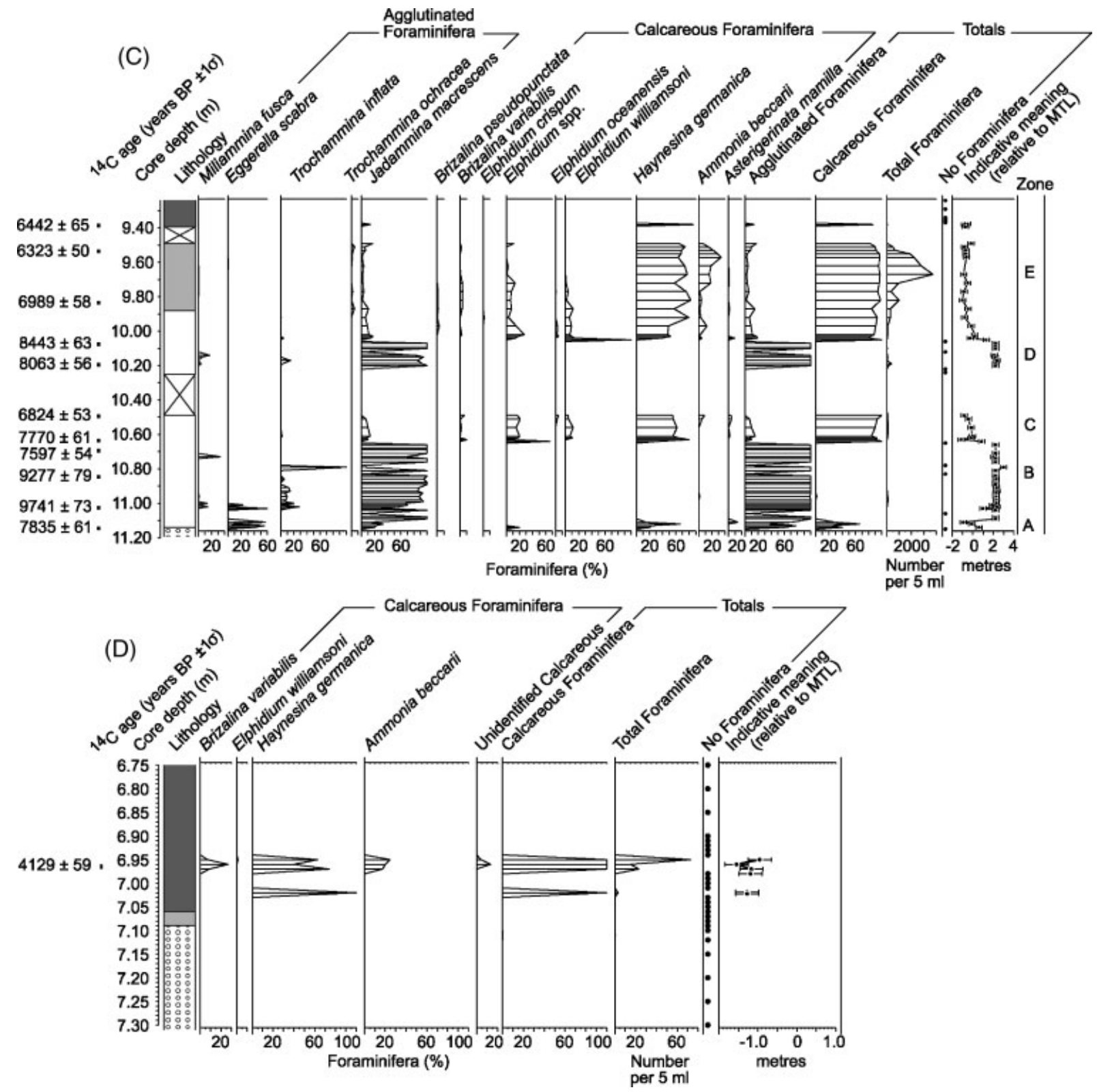

Figure 4 (Continued)

subsidence rates would be lower if global deglaciation continued after ca. 4000 cal. yr BP. Estimates of cessation of global ice melt are frequently revised with respect to the growing body of empirical evidence used to test models (e.g., Peltier, 1994). If we account for global sea-level rise during the past century, the rate of land subsidence in south Devon is reduced by $0.1 \mathrm{~m} \mathrm{ka}^{-1}$. Shennan and Horton (2002) used a linear fit to the sea-level index points to estimate relative land movements. A more realistic approach (on geophysical grounds) is a curvilinear fit which would produce an even lower estimate of relative subsidence.

\section{Differential crustal movements in southwest England}

The relative sea-level history for south Devon can be compared with sea-level data from Cornwall to evaluate differential isostatic movements in southwest England. Healy (1995) provided four basal sea-level index points and three points from intercalated peat units from Marazion Marsh in south- western Cornwall. Waller and Long (2003) discussed four index points collected from peat outcrops on beaches in the Isles of Scilly (Ratcliffe and Straker, 1996) (Table 4). Vertical errors applied to these sea-level index points do not include an estimate of autocompaction.

In Fig. 8(B) we have plotted the sea-level envelope from south Devon, and sea-level index points from Cornwall and the Isles of Scilly in one diagram. The points from Cornwall and the Isles of Scilly span a time period that is poorly covered by the south Devon data. The Isles of Scilly points appear to be positioned within the south Devon envelope, and above the rejected published south Devon index points (36-38). Given the poor constraints on indicative meaning, and the possibility that published index points have been affected by compaction, it is not possible to differentiate between sea-level index points from south Devon, west Cornwall and the Isles of Scilly.

\section{Geophysical model predictions}

This study has added 15 new data points to test geophysical Earth models (e.g., Lambeck, 1993a,b, 1995, 1997; Peltier, 

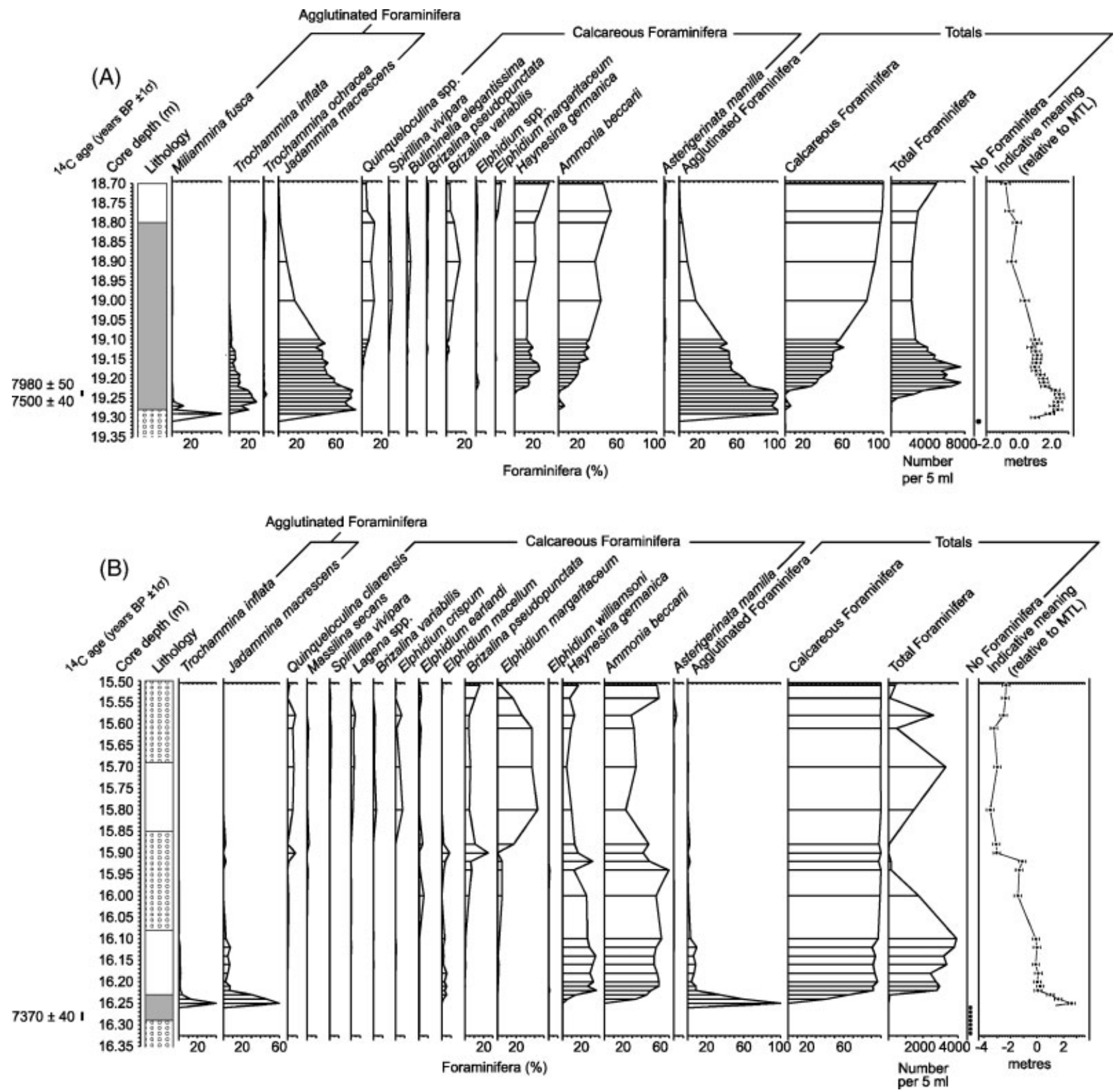

Figure 5 Foraminiferal stratigraphy of Slapton Sands cores SS-99-1 (A) and SS-99-2 (B)

1998; Peltier et al., 2002; Milne et al., 2006; Shennan et al., 2006). Here, we compare our data with the updated GB-3 model of Lambeck (1995) and ICE-5G (VM2) of Peltier (2004) (Fig. 8(A)). We also use predictions by the model of Shennan et al. (2006).

Models differ in their components of the palaeotopography of ice sheets (e.g., ice-equivalent eustatic sea-level rise or the 'eustatic function') and Earth rheology (e.g. see Plag et al., 1998), resulting in different predictions for the timing and altitude of Holocene sea levels along the south Devon coast (Fig. 8(A)). An in-depth comparison between the three models is provided by Shennan et al. (2006). The RSL response from ICE-5G is curvilinear and GB-3 is more rectangular in profile. The Shennan et al. (2006) model prediction is intermediate between the two. The shapes of the curves and the positions of inflection points are a reflection of the 'eustatic function' of the models, i.e. the built-in history of meltwater that is added to the world's oceans. Of the three models, Lambeck's GB-3 generally predicts lower sea-level heights, except between ca. 7000 and 5000 cal. yr BP when GB-3 sea levels are as much as $3 \mathrm{~m}$ higher than those from ICE-5G. The three models are in reasonable agreement with the sea-level data older than ca. 6000 cal. yr BP, but ICE-5G provides the best fit with our sea-level envelope.

The middle to late Holocene south Devon data points plot below the predictions of all three models. Over-prediction of sea-level positions by the models can be resolved by assuming increased melting in the Earth models after ca. $6000 \mathrm{cal}$. yr BP, but these adjustments have a global effect and would produce misfits in other locations. A more regional solution would be to increase ice loads over the British Isles (Shennan et al., 2002) to amplify the 'forebulge effect'. This is an issue that is frequently revised with respect to field evidence, e.g. the height of trim-lines in the Scottish Highlands (Watts, 1977; Ballantyne, 1984; Sutherland, 1991), and is likely to affect rates of crustal movement in the south (Shennan and Horton, 2002). Interestingly, the three model predictions are very close to index point 17 . Comparison with the models shows that additional sea-level data between 4000 and 2000 cal. yr BP would be useful, as the models diverge during this time period. 

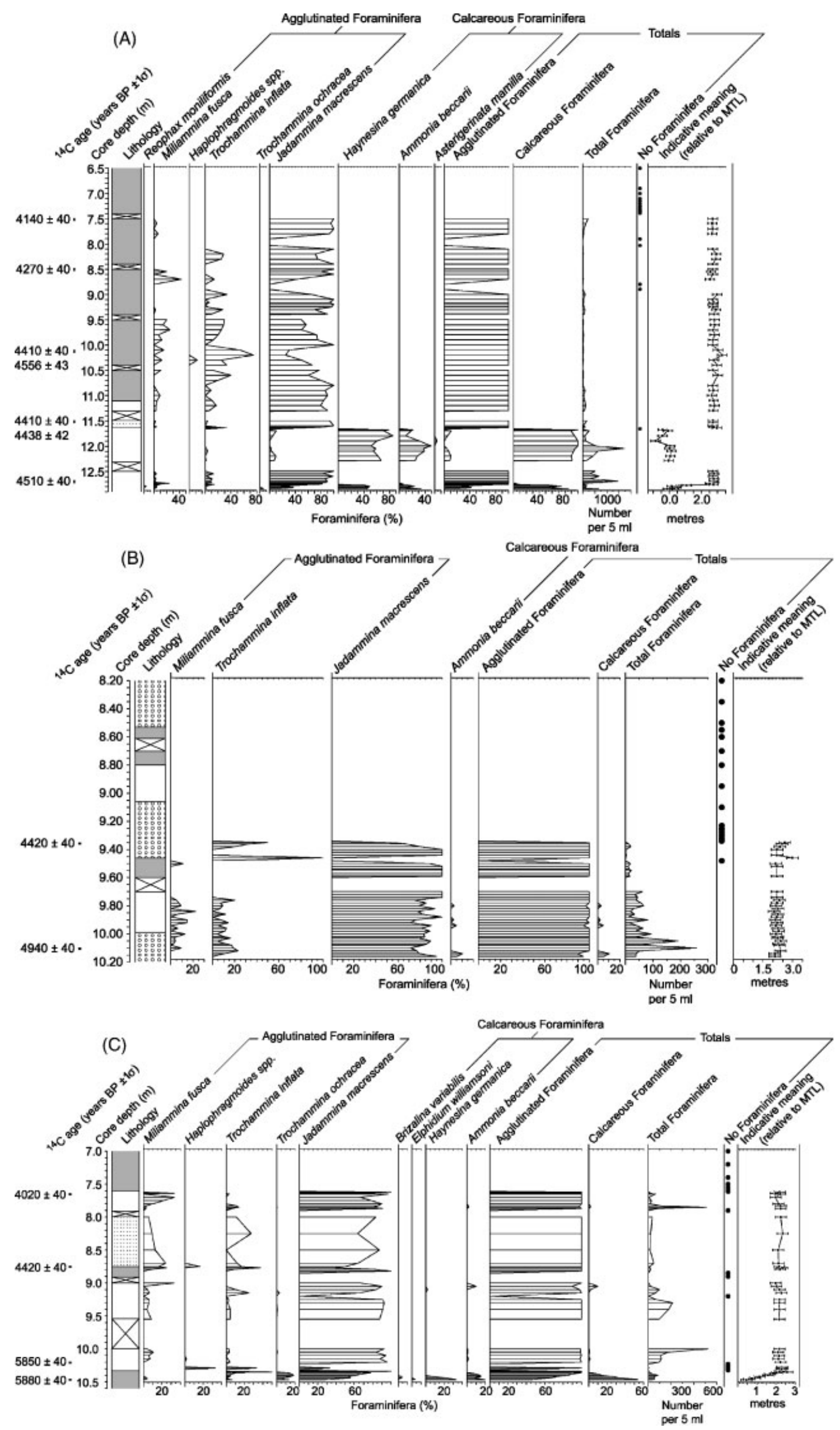

Figure 6 Foraminiferal stratigraphy of Blackpool Sands cores BS-97-1 (A), BS-97-2 (B) and BS-97-3 (C) 
In Fig. 8(B) we compare the south Devon sea-level envelope with index points from west Cornwall and the Isles of Scilly and with predictions for west Cornwall based on the models by Shennan et al. (2006) and ICE-5G by Peltier (2004). Both models place the Cornwall predicted sea-level curves below the Devon predicted curves, with a similar offset (compare Figs $8(\mathrm{~A})$ and $8(\mathrm{~B}))$. The Shennan et al. (2006) model is closer to the late Holocene index points (Fig. 8(B)), whereas the Peltier model shows a slightly better fit with the early to middle Holocene data. Nine of eleven data points, however, plot below the predicted heights. This highlights the need for additional modelling work and the collection of new, highquality sea-level index points.

An important advantage of geophysical models is that they can separate land motion from other processes that contribute to relative sea-level changes. The model by Shennan et al. (2006) predicts that present-day crustal subsidence is $0.85 \mathrm{~mm} \mathrm{yr}^{-1}$ in south Devon and $1.04 \mathrm{~mm} \mathrm{yr}^{-1}$ in west Cornwall. Rates determined by GPS $\left(0.0 \pm 0.5 \mathrm{~mm} \mathrm{yr}^{-1}\right)$ and gravity measurements $\left(0.9 \pm 0.9 \mathrm{~mm} \mathrm{yr}^{-1}\right)$ contain large uncertainties (Teferle et al., 2006) and longer records are required to make fair comparisons with the geophysical model data. The rate for west Cornwall appears high when compared with the Newlyn tide-gauge data $\left(\sim 1.6 \mathrm{~mm} \mathrm{yr}^{-1}\right.$; Woodworth et al., 1999), even when a long-term late Holocene sea-level fall of $\sim 0.3 \mathrm{~mm} \mathrm{yr}^{-1}$ resulting from 'ocean syphoning' is taken into account (Mitrovica and Peltier, 1991; Mitrovica and Milne, 2002). The model-predicted rates of relative sea-level rise are somewhat lower than the estimates of Shennan and Horton
(2002). It is clear, however, that the misfit between model predictions and sea-level index points requires further study and a priority should be the collection of basal sea-level index points covering the late Holocene (i.e. the past $\sim 4000 \mathrm{yr}$ ).

\section{Coastal dynamic processes and implications for sea-level studies}

The sea-level history at Marazion, in southwestern Cornwall, was reconstructed by Healy (1995) (Table 4) from back-barrier sediments and therefore provides interesting comparative material for our work. Healy (1995) concluded that the Marazion water-level history was not only controlled by relative sea-level movements, but also by significant morphodynamical and sedimentary processes. We find a scatter in our sea-level index points which suggests that the back-barrier systems in south Devon have also been affected by processes that complicate the reconstruction of sea-level changes. One such process is the reworking of sediment, for which there is evidence in the stratigraphy of North Sands and Blackpool Sands. The biostratigraphy at these sites is characterised by abrupt changes in foraminiferal populations, whereas foraminiferal changes at Slapton Sands and Bantham Sands are more gradual. This may suggest that the pattern of biostratigraphical changes revealed by foraminifera is a good indicator for the integrity of back-barrier sediments. On this basis we cannot rule out that some of our 'accepted' index points are also

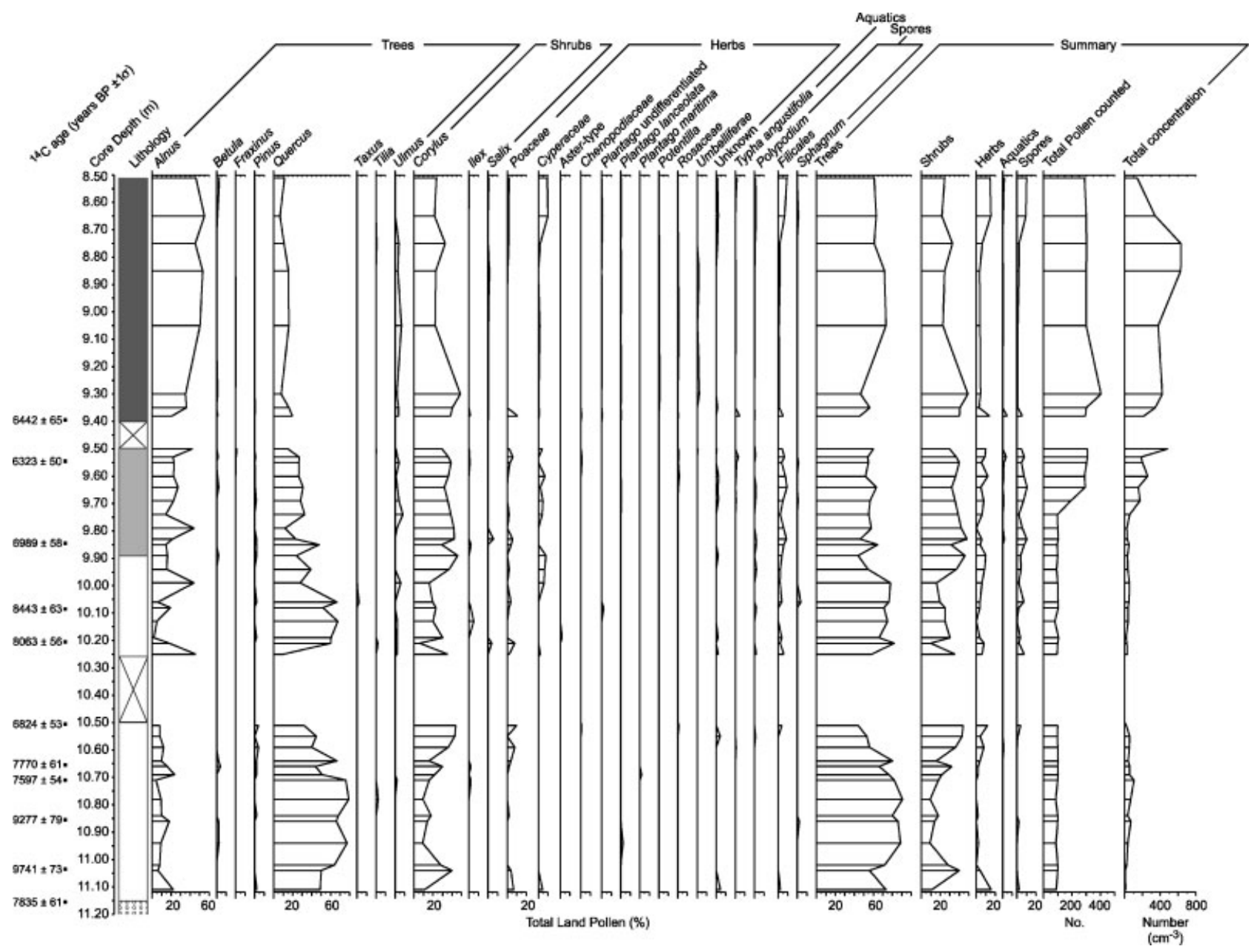

Figure 7 Pollen stratigraphy of core NS-97-3 from North Sands 
Cal. yrs BP

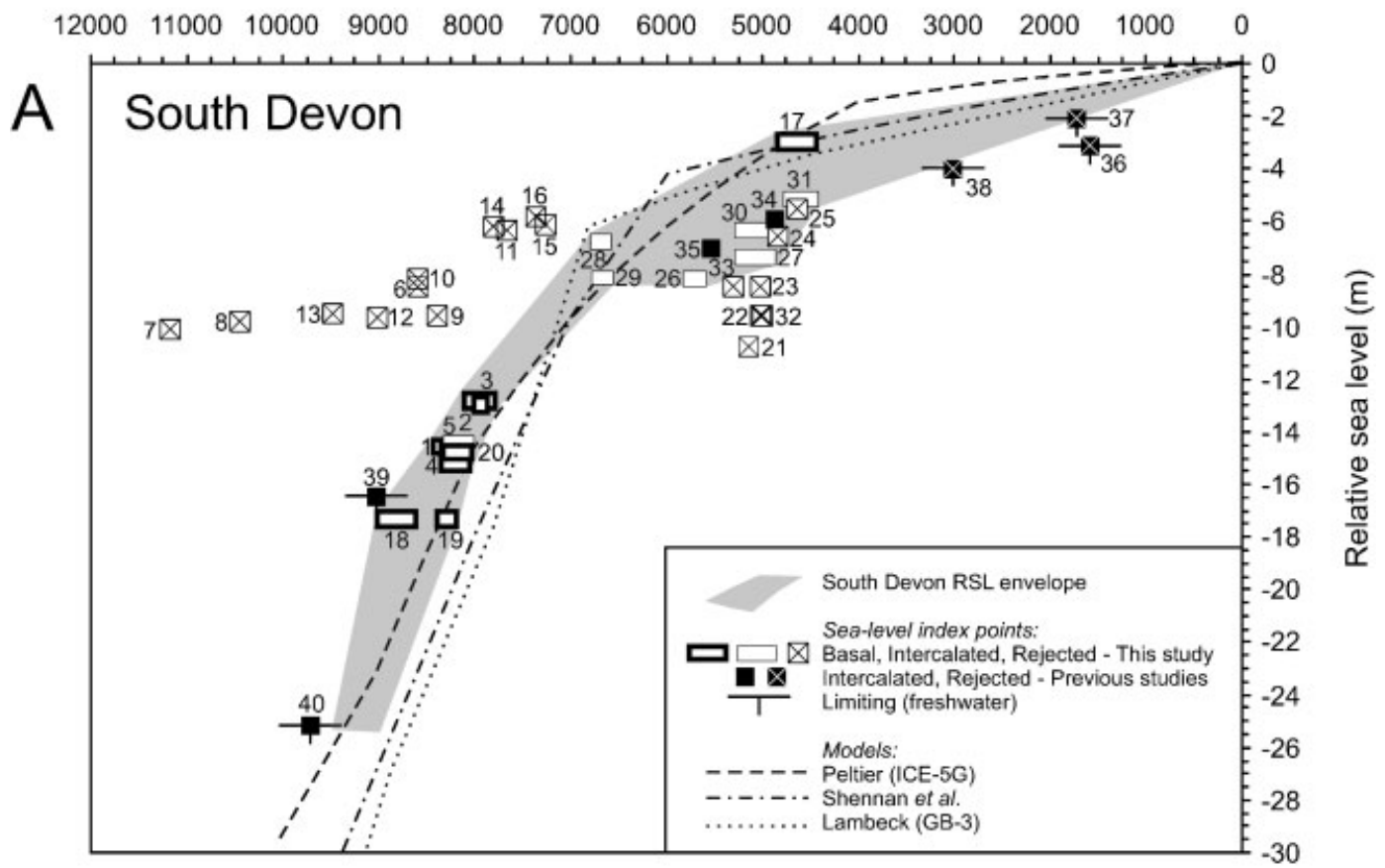

Cal. yrs BP

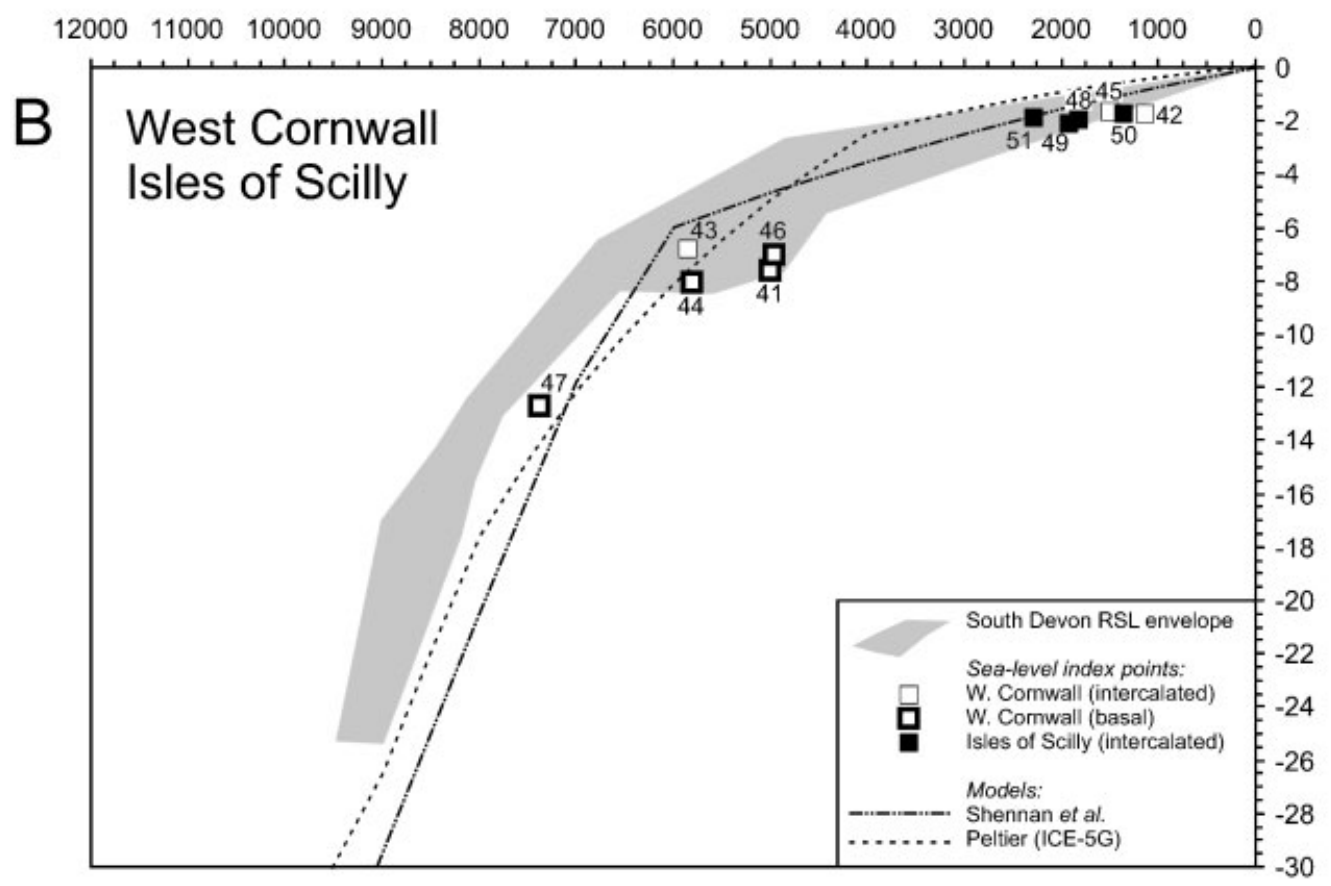

Figure 8 (A) Sea-level index points from south Devon compared with three sea-level curves predicted by geophysical models. The envelope of relative sea-level change encompasses the accepted data points. Index points from this study were corrected for vertical displacement by autocompaction. No corrections were applied to previously published data points. See Table 4 for references of previous studies. Index numbers correspond to Table 2. (B) Sea-level index points for western Cornwall (Healy, 1995) and the Isles of Scilly (Ratcliffe and Straker, 1996) compared with south Devon relative sea-level envelope and model prediction. Index numbers correspond with Table 2. No corrections were applied for possible compaction

affected by sediment reworking. The cluster of index points from Blackpool Sands (26, 27, 30, 31; Fig. 8(A)), for example, appears to be young compared to index points 28 and 29 from the same site, which can be explained by channel bank erosion and redeposition of marsh sediments on the channel floor. A recommendation for future studies from similar environments is that sea-level index points should be obtained, whenever possible, from sedimentary sequences that have been examined for stratigraphical continuity using microfossils.

It is likely that onshore barrier migration during the Holocene rise in sea level was accompanied by reworking and redeposition of sediment as the barriers 'rolled' over the marsh and lagoon deposits behind them. Evidence for this process is 


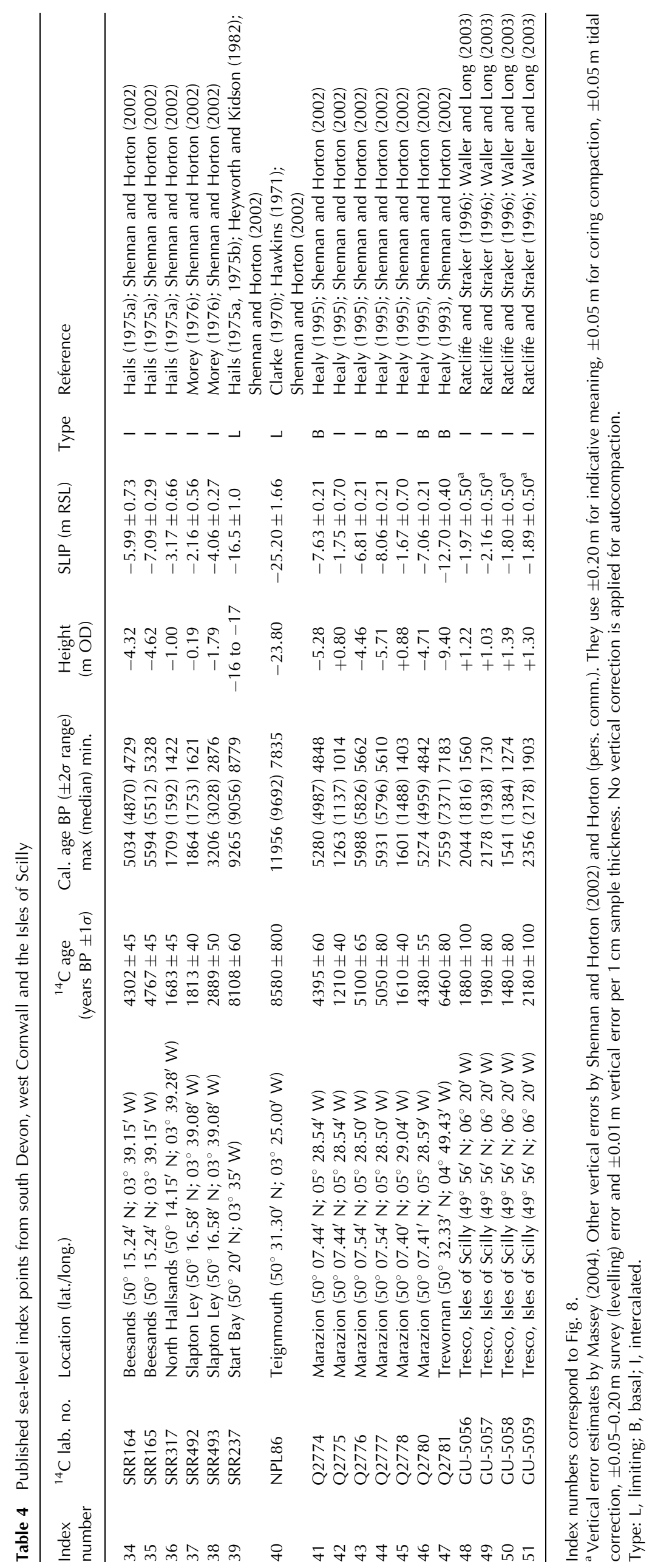



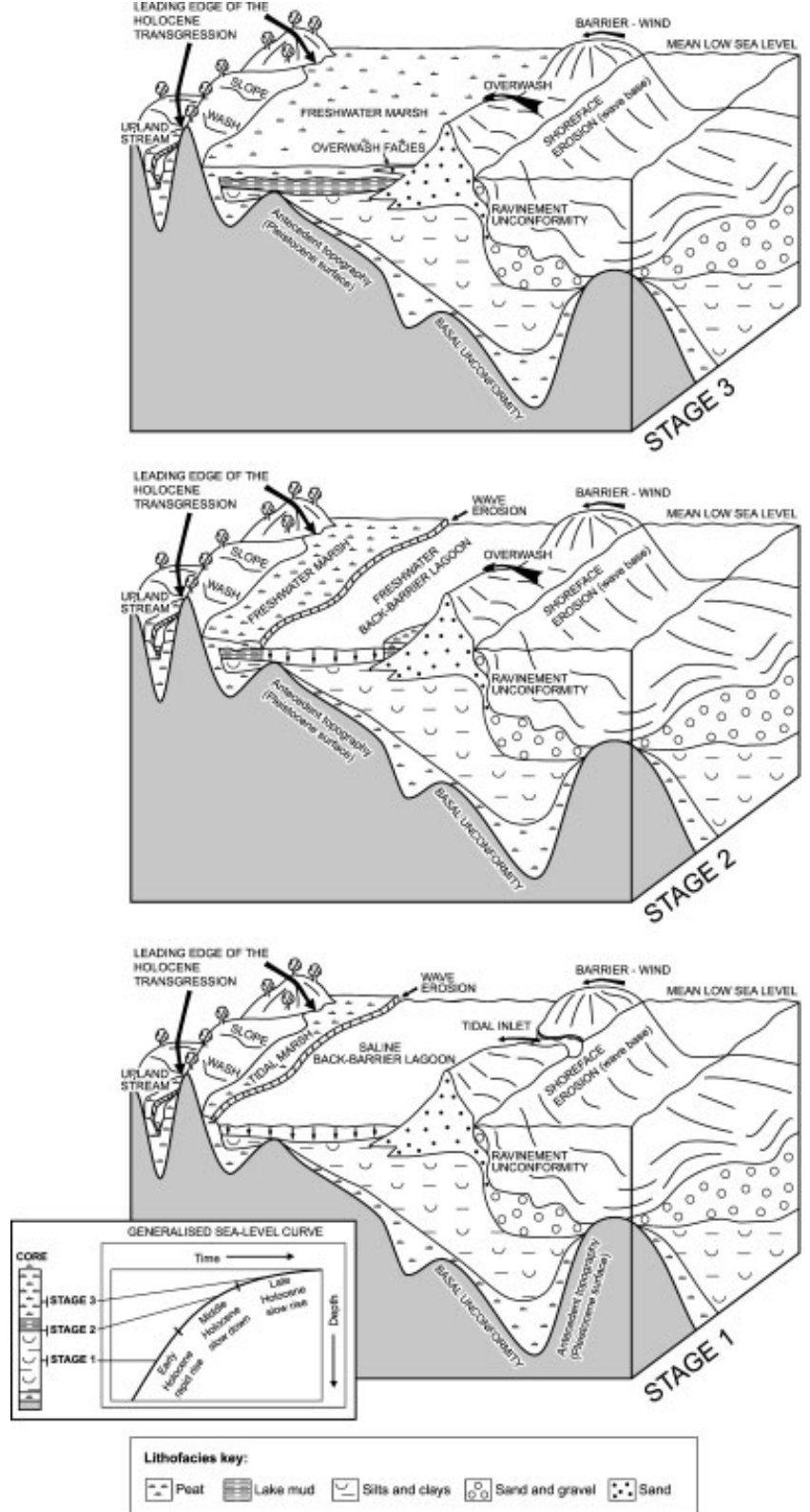

Figure 9 A transgressive model of barrier system development for south Devon. Partly based on Kraft and Chrzastowski (1985). Stage 1: rapid relative sea-level rise during the early Holocene forces barrierlagoon system landward. Stage 2: barrier system closes under decelerating relative sea-level rise during the middle Holocene. Stage 3: infilling of back-barrier system under slow relative sea-level rise during the late Holocene. Inset shows the generalised sea-level curve for south Devon and related schematic lithostratigraphy

found offshore of Slapton Sands and Blackpool Sands where fossil salt-marsh deposits outcrop on the seabed of Start Bay (Hails, 1975a,b). The mouth of the Salcombe-Kingsbridge Estuary, where North Sands is located, is obstructed by a subtidal bar ('The Bar'; Fig. 1(E)), which during low sea levels must have blocked the valley from marine incursions. Several bar-fronted valleys still exist along the coast of south Devon (e.g., at Bantham Sands) and these are filled with freshwater peat deposits. The overtopping of 'The Bar' may have been responsible for the erosion of peat deposits in the SalcombeKingsbridge Estuary palaeovalley, introducing significant quantities of 'old' carbon into the sediments.

In all our sites we find thick minerogenic sequences containing marine microfossils, indicating that barrier systems contained tidal inlets and lagoons before they closed in the later
Holocene. Kraft (1971), Kraft and Chrzastowski (1985) and Belknap and Kraft $(1977,1981,1985)$ describe a transgressive model of landward barrier movement which can be applied to the back-barrier systems of south Devon (Fig. 9). In this model, the preservation of back-barrier sediments is controlled by the antecedent topography and depth of shoreface erosion. A 'ravinement unconformity' is formed by shoreface erosion which moves landward and upward, thereby destroying the top of the back-barrier sequence. The erosion of old back-barrier peat, as found in North Sands, takes place while the ravinement unconformity moves landward under rapidly rising sea level. Internal reworking occurs in the back-barrier lagoon at the edge of the tidal marsh by wave erosion and within the marsh by creek meandering. The latter processes can explain the 'young' ages at Blackpool Sands.

\section{Conclusions}

Fifteen new sea-level index points provide an early to middle Holocene relative sea-level history for the south Devon coast. These data, combined with four previously published index points, show that sea level has risen by $13 \pm 5 \mathrm{~m}$ between ca. 9000 and 7000 cal. yr BP and $8 \pm 1 \mathrm{~m}$ in the past 7000 years. The overall RSL rise since 9000 cal. yr BP has been $21 \pm 4 \mathrm{~m}$. Anomalous ages of rejected samples are explained by a transgressive model of barrier movement, which includes shoreface erosion during barrier migration and reworking of sediments within back-barrier marsh/lagoon systems. Reliable sea-level index points are best obtained from sedimentary sequences where microfossil analyses show evidence of stratigraphical integrity and continuity.

Geophysical model predictions are in good agreement with sea-level index points between 9000 and 6000 cal. yr BP, but the later part of the Holocene is poorly covered by geological observations. Previous estimates of relative land subsidence based on low-quality late Holocene sea-level data need to be reconciled with geophysical model predictions, the Newlyn tide-gauge data and measurements by GPS and gravity methods. Obtaining new late Holocene sea-level data, covering the past 4000 years, is a priority for future sea-level investigations in southwest England.

Acknowledgements This work was part of a PhD project by ACM, funded by the University of Plymouth. Fieldwork was supported by a Royal Society grant to WRG. Site access was granted by the Evans Estate, the South Hams District Council and the Slapton Field Studies Centre. We thank Charlotte Bryant of the NERC Radiocarbon Laboratory for providing radiocarbon ages (allocation nos 835.1299 and 883.0800). Rosemary Drummond, Tony Purcell and Sarah Bradley provided geophysical modelling data. Jason Kirby, Graeme Taylor, Ian King and William Marshall helped with fieldwork. Mike Paul and Richard Hartley assisted with geotechnical laboratory procedures. Ann Kelly helped with pollen preparation. Tim Absalom drafted most figures. Constructive reviews by Jerry Lloyd and Walter Barnhardt improved the paper. This is a contribution to IGCP-Project 495 'Quaternary Land-Ocean Interactions: Driving Mechanisms and Coastal Responses'.

\section{References}

Allen JRL. 1995. Salt-marsh growth and fluctuating sea level: implications of a simulation model for Flandrian coastal stratigraphy and peat-based sea-level curves. Sedimentary Geology 100: 21-45. 
Allen JRL. 1999. Geological impacts on coastal wetland landscapes: some general effects of sediment autocompaction in the Holocene of northwest Europe. The Holocene 9: 1-12.

Allen JRL. 2000. Morphodynamics of Holocene salt marshes: a review sketch from the Atlantic and southern North Sea coasts of Europe. Quaternary Science Reviews 19: 1155-1231.

Andrews R. 1984. A Practical Guide to the British Flora. Quaternary Research Association: Cambridge, UK.

Atterberg A. 1911. Über die physikalische Bodenuntersuchung und über die Plastizität der Tone. Internationale Mitteilungen für Bodenkunde, Berlin 1: 10-43.

Ballantyne CK. 1984. The Late Devensian periglaciation of upland Scotland. Quaternary Science Reviews 3: 311-343.

Belknap DF, Kraft JC. 1977. Holocene relative sea-level changes and coastal stratigraphic units on the northwest flank of the Baltimore Canyon trough geosyncline. Journal of Sedimentary Petrology 47: 610-629.

Belknap DF, Kraft JC. 1981. Preservation potential of transgressive coastal lithosomes on the US Atlantic shelf. Marine Geology 42: 429-442.

Belknap DF, Kraft JC. 1985. Influence of antecedent geology on stratigraphic preservation potential and evolution of Delaware's barrier systems. Marine Geology 63: 235-262.

Bennett KD, Whittington G, Edwards KJ. 1994. Recent plant nomenclature changes and pollen morphology in the British Isles. Quaternary Newsletter 73: 1-6.

Bird MI, Fifield LK, Chua S, Goh B. 2004. Calculating sediment compaction for radiocarbon dating of intertidal sediments. Radiocarbon 46: 421-435.

Birks HJB. 1989. Holocene isochrone maps and patterns of treespreading in the British Isles. Journal of Biogeography 16: 503540

British Standard 1377. 1975. Methods of Test for Soils for Civil Engineering Purposes (BS1377: Numbers 1 to 9: 1990). Gr10, British Standards Institution: London.

British Standard 4691. 1974. Method of Determination of Penetration of Bituminous Materials (BS7020-12: 1988). British Standards Institution: London.

Clarke RH. 1970. Quaternary sediments off southeast Devon. Quarterly Journal of the Geological Society of London 125: 277-318.

de Rijk S. 1995. Agglutinated Foraminifera as indicators of salt marsh development in relation to late Holocene sea level rise. $\mathrm{PhD}$ thesis, Vrije Universiteit, Amsterdam.

Edwards RJ. 2006. Mid- to late-Holocene relative sea-level change in southwest Britain and the influence of sediment compaction. The Holocene 16: 575-587.

Edwards RJ, Horton BP. 2000. Reconstructing relative sea-level change using UK salt-marsh foraminifera. Marine Geology 169: 41-56.

Gehrels WR. 1999. Middle and Late Holocene sea-level changes in eastern Maine reconstructed from foraminiferal saltmarsh stratigraphy and AMS ${ }^{14} \mathrm{C}$ dates on basal peat. Journal of Quaternary Research 52: 350-359.

Gehrels WR. 2002. Intertidal foraminifera as palaeoenvironmental indicators. In Quaternary Environmental Micropalaeontology, Haslett SK (ed.). Arnold: London; 91-114.

Gehrels WR. 2006. Sea-level rise and coastal subsidence in southwest England. Reports and Transactions of the Devonshire Association 138: $25-42$

Gehrels WR, Belknap DF, Kelley JT. 1996. Integrated high-precision analyses of Holocene relative sea-level changes: lessons from the coast of Maine. Geological Society of America Bulletin 108: 1073-1088.

Gehrels WR, Szkornik K, Bartholdy J, Kirby JR, Bradley SL, Heinemeier J, Pedersen JBT, Marshall WA. 2006. Late Holocene sea-level changes and isostasy in western Denmark. Quaternary Research 66: $288-302$.

Grimm EC. 1987. CONISS: a Fortran 77 program for stratigraphically constrained cluster analysis by the method of incremental sum of squares. Computers and Geoscience 13: 13-35.

Hails JR. 1975a. Sediment distribution and Quaternary history of Start Bay, Devon. Journal of the Geological Society, London 131: 19-35.
Hails JR. 1975b. Some aspects of the Quaternary history of Start Bay, Devon. Field Studies 4: 207-222.

Haslett SK, Davies P, Strawbridge F. 1997. Reconstructing Holocene sea-level change in the Severn Estuary and Somerset Levels: the foraminifera connection. Archaeology in the Severn Estuary 8: $29-40$.

Hawkins AB. 1971. The late Weichselian and Flandrian transgression of south west Britain. Quaternaria 14: 115-130.

Healy MG. 1993. Coastal evolution and relative sea-level change in west Cornwall, UK. PhD thesis, National University of Ireland, University College Cork.

Healy MG. 1995. The lithostratigraphy and biostratigraphy of a Holocene coastal sediment sequence in Marazion Marsh, west Cornwall, UK with reference to relative sea-level movements. Marine Geology 124: 237-252.

Heyworth A, Kidson C. 1982. Sea-level changes in southwest England and Wales. Proceedings of the Geologists' Association 93: 91-111.

Hydrographic Office. 2002. Admiralty Tide Tables: United Kingdom and Ireland including European and Channel Ports, Vol. 1. Hydrographer of the Navy, Taunton, UK.

Juggins S. 2003. $C^{2}$ version 1.3: software for ecological and palaeoecological data analysis and visualisation. Department of Geography, University of Newcastle, Newcastle upon Tyne, UK.

Kraft JC. 1971. Sedimentary facies patterns and geologic history of a Holocene marine transgression. Geological Society of America Bulletin 82: 2131-2158.

Kraft JC, Chrzastowski MJ. 1985. Coastal stratigraphic sequences. In Coastal Sedimentary Environments, Davis RA Jr (ed.). Springer: New York; 625-663.

Lambeck K. 1993a. Glacial rebound of the British Isles. I. Preliminary model results. Geophysical Journal International 115: 941-959.

Lambeck K. 1993b. Glacial rebound of the British Isles-II: A high resolution, high-precision model. Geophysical Journal International 115: 960-990.

Lambeck K. 1995. Late Devensian and Holocene shorelines of the British Isles and North Sea from models of glacio-hydro-isostatic rebound. Journal of the Geological Society, London 152: 437 448 .

Lambeck K. 1997. Sea-level change along the French Atlantic and Channel coasts since the time of the Last Glacial Maximum. Palaeogeography Palaeoclimatology Palaeoecology 129: 1-22.

Loeblich AR, Tappan H. 1987. Foraminiferal Genera and their Classification. Van Nostrand Reinhold: New York.

Massey AC. 2004. Holocene sea-level changes along the Channel coast of south-west England. PhD thesis, University of Plymouth, UK.

Massey AC, Gehrels WR, Charman DJ, White SV. 2006a. An intertidal foraminifera-based transfer function for reconstructing Holocene sea-level change in southwest England. Journal of Foraminiferal Research 36: 215-232.

Massey AC, Paul MA, Gehrels WR, Charman DJ. 2006b. Autocompaction in Holocene coastal back-barrier sediments from south Devon, southwest England, UK. Marine Geology 226: 225-241.

Massey AC, Taylor GK, Gehrels WR, Charman DJ. 2006c. The electrical resistivity of coastal back-barrier sediments in south Devon, southwest England, UK. Journal of Coastal Research 22: 1179-1191.

Milne GA, Shennan I, Youngs BAR, Waugh AI, Teferle FN, Bingley RM, Bassett SE, Cuthbert-Brown C, Bradley SL. 2006. Modelling the glacial isostatic adjustment of the UK region. Philosophical Transactions of the Royal Society: Mathematical, Physical and Engineering Sciences (Series A) 364: 931-948.

Mitrovica JX, Milne GA. 2002. On the origin of late Holocene sea-level highstands within equatorial ocean basins. Quaternary Science Reviews 21: 2179-2190.

Mitrovica JX, Peltier WR. 1991. On postglacial geoid subsidence over the equatorial oceans. Journal of Geophysical Research 96(B12): 20053-20071.

Moore PD, Webb JA, Collinson ME. 1991. Pollen Analysis (2nd edn). Blackwell Scientific: London.

Morey CR. 1976. The natural history of Slapton Ley Nature Reserve IX: The morphology and history of the lake basins. Field Studies 4: 353-368.

Mörner N-A. 1984. Planetary, solar, atmospheric and endogene processes as origin of climatic changes on the Earth. In Climatic Changes 
on a Yearly to Millennial Basis, Mörner N-A, Karlen W (eds). Reidel: Dordrecht; 483-507.

Murray JW. 1979. British nearshore foraminiferids: keys and notes for the identification of the species. In Synopses of the British Fauna (New Series), No. 16 Kermack DM, Barnes RSK (eds). Academic Press: London; 1-68.

Parker AG, Goudie AS, Anderson DE, Robinson MA, Bonsall C. 2002. A review of the mid-Holocene elm decline in the British Isles. Progress in Physical Geography 26: 1-45.

Paul MA, Barras BF. 1998. A geotechnical correction for postdepositional sediment compression: examples from the Forth Valley, Scotland. Journal of Quaternary Science 13: 171-176.

Peltier WR. 1974. The impulse response of a Maxwell Earth. Reviews of Geophysics 12: 649-669.

Peltier WR. 1994. Ice age palaeotopography. Science 265: 195-201.

Peltier WR. 1998. Postglacial variations in the level of the sea: implications for climate dynamics and solid-Earth geophysics. Reviews of Geophysics 36: 603-689.

Peltier WR. 2004. Global glacial isostasy and the surface of the ice-age Earth: the ICE-5G (VM2) model and GRACE. Annual Review of Earth and Planetary Sciences 32: 111-149.

Peltier WR, Shennan I, Drummond R, Horton BP. 2002. On the postglacial isostatic adjustment of the British Isles and the shallow visco-elastic structure of the Earth. Geophysical Journal International 148: $443-475$.

Pizzuto JE, Schwendt AE. 1997. Mathematical modelling of autocompaction of a Holocene transgressive valley-fill deposit, Wolfe Glade, Delaware. Geology 25: 57-60.

Plag H-P, Engen B, Clark TA, Degnan JJ, Richter B. 1998. Post-glacial rebound and present-day three-dimensional deformations. Journal of Geodynamics 25: 263-301.

Ratcliffe J, Straker V. 1996. The Early Environment of Scilly. Cornwall Archaeological Unit, Cornwall County Council: Truro, UK.

Rees JG. 1999. LOEPS Logging Protocol. Coastal Geology Group BGS Report, Keyworth, UK.

Rybczyk JM, Callaway J, Day JW Jr. 1998. A relative elevation model (REM) for a subsiding coastal forested wetland receiving wastewater effluent. Ecological Modelling 112: 23-44.

Scott DB, Medioli FS. 1980a. Living vs. total populations: their relative usefulness in palaeoecology. Journal of Palaeontology 54: 814831.

Scott DB, Medioli FS. 1980b. Quantitative studies of marsh foraminiferal distributions in Nova Scotia: implications for sea-level studies. Cushman Foundation for Foraminiferal Research Special Publication, No.17.

Shennan I. 1983. Flandrian and Late Devensian sea-level changes and crustal movements in England and Wales. In Shorelines and Isostasy, Smith DE, Dawson AG (eds). Institute of British Geographers Special Publication No.16. Academic Press: London; 255-283.

Shennan I. 1989. Holocene crustal movements and sea-level changes in Great Britain. Journal of Quaternary Science 4: 77-89.

Shennan I, Horton B. 2002. Holocene land- and sea-level changes in Great Britain. Journal of Quaternary Science 17: 511-526.
Shennan I, Peltier WR, Drummond R, Horton B. 2002. Global to local scale parameters determining relative sea-level changes and the post-glacial isostatic adjustment of Great Britain. Quaternary Science Reviews 21: 397-408.

Shennan I, Bradley S, Milne G, Brooks A, Bassett S, Hamilton S. 2006. Relative sea-level changes, glacial isostatic modelling and ice-sheet reconstructions from the British Isles since the Last Glacial Maximum. Journal of Quaternary Science 21: 585-599.

Stace C. 1991. New Flora of the British Isles. Cambridge University Press: Cambridge, UK.

Stuiver M, Reimer PJ. 1993. Extended ${ }^{14} \mathrm{C}$ data base and revised CALIB. $3.0{ }^{14} \mathrm{C}$ age calibration program. Radiocarbon 35: 215-230.

Stuiver M, Reimer PJ, Bard E, Beck JW, Burr GS, Hughen KA, Kromer B, McCormac G, van der Plicht J, Spurk M. 1998. INTCAL98 Radiocarbon Age Calibration, $24000-0$ cal BP. Radiocarbon 40: 1041-1083.

Sutherland DG. 1991. The glaciation of the Shetland and Orkney Islands. In Glacial Deposits in Great Britain and Ireland, Ehlers J, Gibbard PL, Rose J (eds). Balkema: Rotterdam; 121-127.

Teferle FN, Bingley RM, Williams SDP, Baker TF, Dodson AH. 2006. Using continuous GPS and absolute gravity to separate vertical land movements and changes in sea-level at tide-gauges in the UK. Philosophical Transactions of the Royal Society: Mathematical, Physical and Engineering Sciences (Series A) 364: 917-930.

Terzaghi K. 1925. Erdbaumechanik auf bodenphysikalischer grundlage. Deuticke, Vienna, Casagrande A (transl., 1960). In From Theory to Practice in Soil Mechanics. Wiley: New York.

Terzaghi K, Peck RB, Mesri G. 1996. Soil Mechanics in Engineering Practice (3rd edn). Wiley: Chichester.

Tovey NK, Paul MA. 2002. Modelling self-weight consolidation in Holocene sediments. Bulletin of the International Association of Engineering Geologists 61: 21-33.

Troels-Smith J. 1955. Karakterising af løse jordater (characterisation of unconsolidated sediments). Danmarks Geologiske Undersøgelse, IV Series 3.

Ussher WAE. 1904. The geology of the country around Kingsbridge and Salcombe (explanation of Sheets 355 and 356). Memoirs of the Geological Survey of England and Wales.

Walcott RI. 1970. Flexural rigidity, thickness and viscosity of the lithosphere. Journal of Geophysical Research 75: 3941-3954.

Waller MP, Long AJ. 2003. Holocene coastal evolution and sea-level change on the southern coast of England: a review. Journal of Quaternary Science 18: 351-359.

Watts WA. 1977. The Late Devensian vegetation of Ireland. Philosophical Transactions of the Royal Society, London B280: 273293.

Williams H. 2003. Modeling shallow autocompaction in coastal marshes using cesium-137 fallout: preliminary results from the Trinity River Estuary, Texas. Journal of Coastal Research 19: 180-188.

Woodworth PL, Tsimplis MN, Flather RA, Shennan I. 1999. A review of the trends observed in British Isles mean sea level data measured by tide gauges. Geophysical Journal International 136: 651-670. 